Andrews University

Digital Commons @ Andrews University

2000

\title{
Using the Heritage of the St. Thomas Christians To Develop an Outreach Strategy
}

Kunjunjukutty Yohannan

Andrews University

Follow this and additional works at: https://digitalcommons.andrews.edu/dmin

Part of the Practical Theology Commons

\section{Recommended Citation}

Yohannan, Kunjunjukutty, "Using the Heritage of the St. Thomas Christians To Develop an Outreach Strategy" (2000). Professional Dissertations DMin. 693.

https://dx.doi.org/10.32597/dmin/693

https://digitalcommons.andrews.edu/dmin/693

This Project Report is brought to you for free and open access by the Graduate Research at Digital Commons @ Andrews University. It has been accepted for inclusion in Professional Dissertations DMin by an authorized administrator of Digital Commons @ Andrews University. For more information, please contact repository@andrews.edu. 
ABSTRACT

USING THE HERITAGE OF THE ST. THOMAS CHRISTIANS

TO DEVELOP AN OUTREACH STRATEGY

by

Kunjunjukutty Yohannan

Adviser: Gordon Christo 


\title{
ABSTRACT OF GRADUATE STUDENT RESEARCH
}

Dissertation

\author{
Andrews University \\ Seventh-day Adventist Theological Seminary
}
Title: USING THE HERITAGE OF THE ST. THOMAS CHRISTIANS TO DEVELOP AN OUTREACH STRATEGY

Name of researcher: Kunjunjukutty Yohannan

Name and degree of faculty adviser: Gordon Christo, Ph.D. Date completed: September 2000

\section{Problem}

The St. Thomas Christians in Kerala claim their spiritual heritage from Thomas the apostle. Yet they are not generally aware of a number of scriptural teachings including the seventh-day Sabbath, which Thomas and their forefathers observed. For the last one hundred years there has been no developed Seventh-day Adventist strategy to proclaim the full biblical message, which was their heritage, to this people group.

\section{Findings}

The St. Thomas Christians of Kerala, India, believe that Thomas the apostle took Christianity to India. Their very existence bears witness to it. 
Thomas is reported to have arrived in Kerala in A.D. 52. He preached among the settled Jews and Hindus and established churches.

The St. Thomas Christians practiced a simple faith as taught by the apostle. They had two sacraments, baptism and Lord's Supper, and they worshiped only on Saturday at least until the fourth century. They followed the syriac liturgy. Until the sixteenth century they had ties with East syrian (Persian) churches. They continued their Sabbath observance throughout this period.

In the sixteenth century the St. Thomas Christians came into contact with the Roman Catholics. The subsequent establishment of the Inquisition and the Latinization program led to the synod of Diamper (1599) and later to the Humbled Cross Oath in 1653. After the St. Thomas Christians came under Roman Catholicism, the church began to fracture. Using as a bridge the history and ancient doctrines of the St. Thomas Christians, especially the observance of the seventh-day Sabbath, a strategy was developed to evangelize nominal st. Thomas Christians in Kerala. It includes a preevangelism program for two months with various awareness programs, Bible study, and the organization of succeeding events. This is to be followed by an evangelistic crusade for 21 days, emphasizing the faith and practices of st. Thomas Christians. The final step will be the formation of 
a church and postbaptismal care, which include spiritual growth programs, a life development institute, cell group ministry, and erecting a church building for the congregation. 


\author{
Andrews University \\ Seventh-day Adventist Theological Seminary
}

USING THE HERITAGE OF THE ST. THOMAS CHRISTIANS

TO DEVELOP AN OUTREACH STRATEGY

\author{
A Dissertation \\ Presented in Partial Fulfillment \\ of the Requirements for the Degree \\ Doctor of Ministry
}

by

Kunjunjukutty Yohannan

September 2000 



\section{USING THE HERITAGE OF THE ST. THOMAS CHRISTIANS}

\section{TO DEVELOP AN OUTREACH STRATEGY}

A dissertation

presented in partial fulfillment of the requirements for the degree

Doctor of Ministry

by

Kunjunjukutty Yohannan

APPROVAL BY THE COMMTTEE:

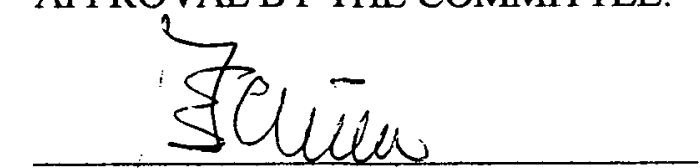

Adviser,

Gordon E. Christo

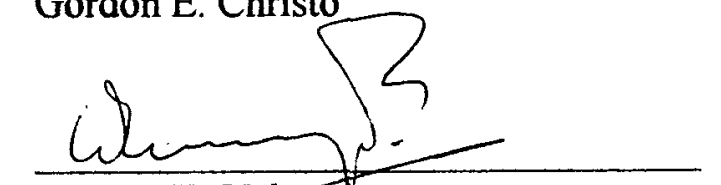

Werner K. Vyhmepster
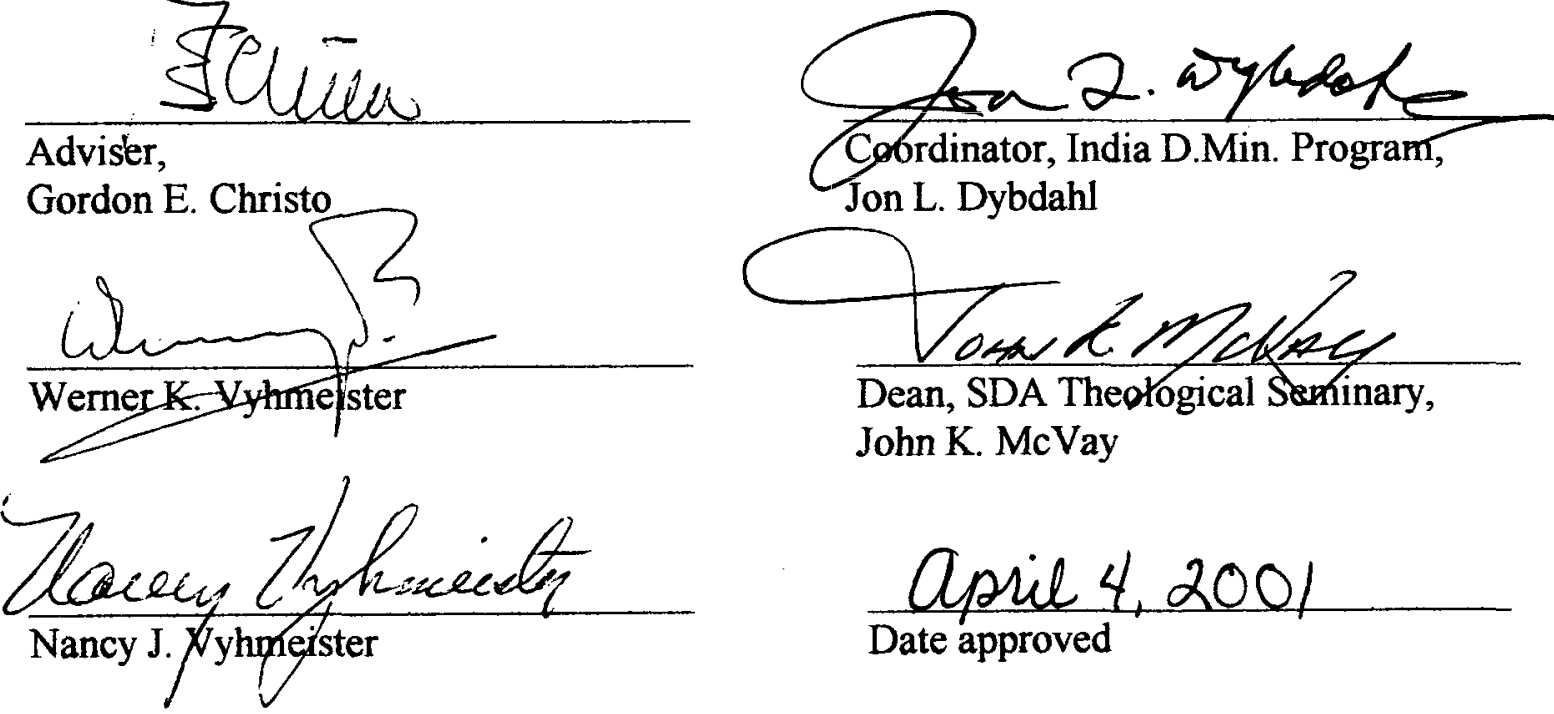

Jon L. Dybdahl

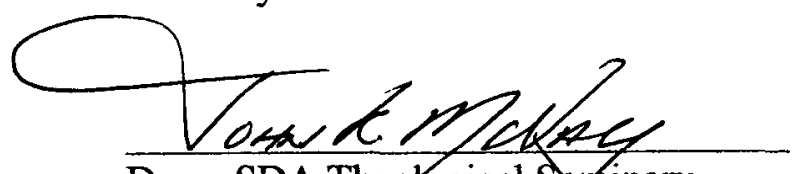

Dean, SDA Theotogical Seminary,

John K. McVay

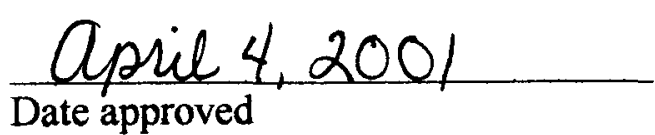


Dedicated to the Glory of God and my beloved professor and adviser, Gordon Christo 
TABLE OE CONTENTS

ACKNOWLEDGMENTS . . . . . . . . . . . . . . . . . . . . . . . vii

Chapter

1. INTRODUCTION $\cdot$. . . . . . . . . . . . . . . . 1

Statement of the Task . . . . . . . . . . 1

Justification for Dissertation . . . . . . . . 1

Overview of the Dissertation . . . . . . . . . 2

Definition of Terms . . . . . . . . . . . . 3

Kerala •. •. . . . . . . . . . . . . . 3

2. THE APOSTLE THOMAS . . . . . . . . . . . . . 6

Thomas in the Gospels . . . . . . . . 6

The Doubter . . . . . . . . . . . 6

The Confession . . . . . . . . . . 9

The Commission . . . . . . . . . . 9

Thomas in Other Sources . . . . . . . . 10

The Acts of Thomas . . . . . . . . . . 11

Archaeological Evidence . . . . . . . . 13

The Church Fathers . . . . . . . . . . 14

Thomas According to Indian Tradition . . . . 16

Local Traditions . . . . . • . • • . 17

His First Missionary Journey . . . . . . 19

Return to Jerusalem . . . . . . . . . 21

Coming to the Land of Cheras . . . . . . 22

His Converts . . . . . . . . . . . . . 24

The Marriage of the Princess of

Cranganore . . . . . . . . . . . 25

Kurakeni and the Church of Paravoor . . . 27

The Water of Palayur . . . . . . . . 27

The Log at Mylapore . . . . . . . . . 29

His Martyrdom . . . . . . . . . . . 30

Historical Factors to Be Considered . . . . . 31

The Sea Route . . . . . . . . . . . 31

Presence of Jews in Kerala . . . . . . 33

The Coming of the Jews to Kerala . . 33

The Number of Jews in Kerala in

the First Century . . . . . . . 35

Evidences of Their Presence. . . . . 36 
3. LEGACY OF ST. THOMAS ............ . 40

St. Thomas Christians until 1500 . . . . . 40

St. Thomas Christians in the Second

through Fourth Centuries . . . . . 41

Thomas of Cana . . . . . . . . . . 44

Privileges of Jews and Christians . . . . 47

Relations with the West....... . 51

The Syriac Connection .. . . . . . . 51

The Nestorian Connection . . . . . . . 53

St. Thomas Christians and the Roman Catholics . 56

Inquisition . . . . . . . . . . . 57

Synod of Diamper 1599 . . . . . . . . . 60

Oath at the Humbled Cross . . . . . . 64

4. EVIDENCES OF SABBAth KeEPING.......... 66

The First Six Centuries . . . . . . . . 67

Jewish Christians . . . . . . . . 67

Non-Jewish Christians . . . . . . . . 68

Seventh to Sixteenth Centuries . . . . . . 71

The Nestorian Connection . . . . . . . . 71

The Goa Inquisition . . . . . . . . 72

Synod of Diamper . . . . . . . . . . . 75

Recent References ........... . 77

5. THE FRACTURING OF THE ST. THOMAS CHRISTIANS . . 80

The Syro-Malabar Church . . . . . . . 80

The Syro-Malankara Church . . . . . . . 83

Syrian Orthodox Church . . . . . . . . . 85

Independent Syrian Church or Thozhiyoor

Church . . . . . . . . . . . 86

The Malankara Jacobite Syrian Orthodox Church . 88

The Church of the East or the Surrays . . . . 89

Mar Thomite Church . . . . . . . . . . 90

Central Kerala Diocese of the Church of South

India . . . . . . . . . . . . . 93

St. Thomas Evangelical Church of India . . . 94

Conclusion . . . . . . . . . . . 95

6. STRATEGY FOR REACHING THE ST. THOMAS CHRISTIANS

IN PALLIPAD . . . . . . . . . . . . . . . . . . . 97

The Target Group . . . . . . . . . . . 98 Justification for a People Group Approach . 98 Location and Numbers . . . . . . . 100 
Occupation and Economy .. . . . . . 102

Their Lifestyle. . . . . . . . . . . 104

Preevangelism Period . . . . . . . . . 107

Planning the Evangelism . . . . . . . 107

Purpose and Objectives . . . . . 108

Resources ............ 109

Formation of Committees . . . . . . 109

Steering Committee . . . . . . . 110

Finance Committee . . . . . . . 110

Pandal or Hall Committee . . . . . 111

Publicity Committee . . . . . . . 112

Transportation Committee . . . . 114

Bible-Marking Plan Committee . . . 114

Visitation Committee . . . . . . 114

Music Committee . . . . . . . . 115

Platform Committee . . . . . . 116

Health Committee . . . . . . . 116

Usher Committee . . . . . . . . 117

Baptism Committee . . . . . . . . 118

Building Relationships with Local

Authorities and People . . . . . 118

Felt-Needs Evangelism . . . . . . . . 118

ADRA . . . . . . . . . . . . 120

Five-day Plan to Stop Smoking . . . 121

Free Medical Services . . . . . . 121

Youth Programs . . . . . . . . 121

SDA Media Promotion . . . . . . . . 122

VOP Enrollment and Rally . . . . 122

Adventist World Radio... . . . . 122

Television . . . . . . . . . . 123

Bible Studies... . . . . . . . . 124

Prayer Preparation . . . . . . . . 124

Public Meeting Period . . . . . . . . . . 127

Daily Program . . . . . . . . . . . 127

Opening Night . . . . . . . . . . . 128

Topics Covered . . . . . . . . . . . 129

Baptism . . . . . . . . . . . . 131

Preparation . . . . . . . . . 131

Ceremony . . . . . . . . . . 132

Post-Baptismal Care . . . . . . . . . . 132

Worship . . . . . . . . . . . . 133

School for Children . . . . . . . . 134

Life Development Institute . . . . . . 135

Cell Groups. . . . . . . . . . . 136

Church Building . . . . . . . . . . . 138 
7. SUMMARY, CONCLUSIONS, AND RECOMMENDATIONS • • 140 Summary ................ . 140 Conclusions . . . . . . . . . . . . . . 142 Recommendations ............ . 143 APPENDIX . . . . . . . . . . . . . . 145 BIBLIOGRAPHY ............... . . 146

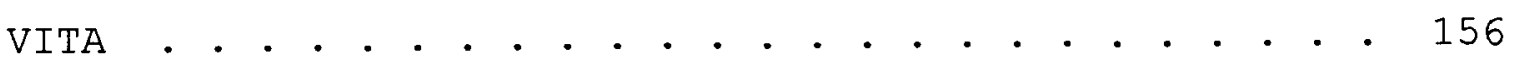




\section{ACKNOWLEDGMENTS}

It is appropriate to first of all acknowledge my gratitude to God the Almighty for His boundless blessing and superb leading in my life, particularly for leading in the completion of this topic.

I am grateful to Dr. Gordon Christo for the unreserved and tireless assistance he provided me as the chairperson of this dissertation.

I am thankful to Dr. M. E. Cherian, former president of the Southern Asia Division, for including me in this program. I am also thankful to Pastor D. R. Watts, the President of the Southern Asia Division of the SDA Church, for his continued assistance.

I am thankful to Dr. Nancy Vyhmeister for her remarkable ability in teaching and helping me with this paper, which otherwise would have been an impossible task.

I am grateful to Dr. Jon Dybdahl for shaping my paper towards its completion.

I am thankful to Dr. Bruce Bauer for initiating this program, for teaching practical lessons, and for helping me in this research. I am also grateful to Mrs. Linda Bauer who helped me in editing the paper. 
I must also record my deep appreciation and thanks to Dr. Werner Vyhmeister for his final touch towards completion of my paper.

I must record my thanks to Monita Soreng and Nigel Soreng, who spent sleepless nights typing my paper when it was urgently called for.

I am greatly overwhelmed and express my gratitude to my wife Thankamma, my daughter, Tinu, and my son, Tiju, for their patience and forbearance during my stay away from home and for their prayers and encouragement.

Finally, I am deeply grateful to the South India Union officers and Division officers for the financial support which was so graciously given to help me to complete my studies. 
CHAPTER I

INTRODUCTION

The Seventh-day Adventist (SDA) Church has not taken root among the St. Thomas Christians in Kerala. One reason for this is that the St. Thomas Christians are not aware that they and SDAs share a common heritage derived from the teaching of St. Thomas who came to India in the first century A.D. St. Thomas Christians are generally unaware that their spiritual foreparents observed any day other than Sunday, as they do now.

\section{Statement of the Task}

The task of this dissertation is to document the evidence that the st. Thomas Christians in Kerala kept the seventh-day Sabbath and turn this knowledge into a bridge to evangelism in Kerala.

\section{Justification for the Dissertation}

The majority of the St. Thomas Christians believe that the seventh-day Sabbath is meant to be observed only by Jews, not by Christians. They are not aware that their forefathers kept the seventh-day Sabbath. This study will 
provide the evidence to inform them of their spiritual heritage.

The St. Thomas Christians feel that they are the advocates of true Christianity in Kerala and yet they do not recognize the scriptural teaching of the seventh-day Sabbath.

Many of the Seventh-day Adventist pioneers in Kerala did not attempt to investigate the evidence regarding Sabbath keeping among st. Thomas Christians. Seventh-day Adventist believers need to deepen their understanding of the Sabbath in order to be witnesses of the truth.

A strategy to present the Bible teachings to individual target groups in harmony with their own cultural background has not been developed in Kerala.

\section{The Overview of the Dissertation}

Chapter 2 presents the life and history of St. Thomas. In chapter 3 the legacy of St. Thomas is described, from his time to the coming of the Roman Catholics around 1500. Chapter 4 presents evidences that the St. Thomas Christians observed the Sabbath until the sixteenth century. In chapter 5 the reader will find a description of the groups into which the original st. Thomas Church has splintered since the seventeenth century. Chapter 6 presents a 
strategy to attract nominal St. Thomas Christians to the Adventist communion. Finally, chapter 7 summarizes the dissertation and presents conclusions and recommendations.

\section{Definition of Terms}

Malabar: Another name for Kerala.

Spice Land: Another name for Kerala.

Cheranadu: Another name for Kerala.

Travancore: Another name for Kerala.

Malpan: A title for a priest.

Cathanar: Another title for a priest.

Nazaranis: Another name for St. Thomas Christians.

Padroado: Catholic missionary activities under the control of Portuguese rule.

Propaganda: The organization responsible for the direction and administration of Roman Catholic missionary activities created in 1662 by Gregory XV.

\section{Kerala}

Kerala is the state in India occupying the narrow strip of land (between 25 to 85 miles wide) between the Western Ghats and the Arabian Sea, stretching from Cape Comorin, the southern tip of India, about 359 miles northwards. Gokakarnam, a little to the north of Mt. Ely or Ezhimala, is generally considered to be the northern boundary of Kerala. 
Kerala was the kingdom of Chera, known as Keralaputra (Son of Kerala). The capital of the Chera rulers was Muziris, derived from Greek, and corresponds to Muchiri of Tamil literature. It is identified by most scholars as Kodungallur or Cranganore, as it is known in the European languages.

Geographically, Kerala may be divided into three regions. The highland slope down from the Western Ghats rises to an average height of $900 \mathrm{~m}$., with a number of peaks well over $1800 \mathrm{~m}$. in height. This is the area of plantations of tea, coffee, rubber, cardamom, and other spices.

The middle lands, lying between the mountain and the lowlands, are made up of undulating hills and valleys. This is an area of intensive cultivation. Cashews, coconut, areca or betel nut, cassava (tapioca), bananas, rice, ginger, pepper, sugarcane, and vegetables of different varieties are grown in this area.

The lowlands or the coastal area, which is made up of the river belts, backwaters, and the shore of the Arabian Sea, is essentially a land of coconut and rice. Fisheries and the coir (coconut fibre) industry constitute the major industries of this area.

Kerala has an area of 38,863 square kilometers which is only 1.18 percent of the total area of India, but the state 
has 7.43 percent of the total population. According to the 1999 census, the population was $29,698,518$. The population growth rate from 1981 to 1991 was 13.98 percent. ${ }^{1}$ The population density per square kilometer was 747 . The literacy rate has reached 90.59 percent. ${ }^{2}$

Kerala has been the home of different religions from time immemorial, and is one of the oldest centers of Christianity in the world. The Christian religion has struck its roots deep in the soil of this land.

${ }^{1}$ Malayala Manorama Year Book (Kottayam, Kerala: Manorama Press, 1999), 636.

${ }^{2}$ Ibid. 
CHAPTER II

THE APOSTLE THOMAS

This chapter traces the life of Thomas. In doing so, various sources are examined: the Gospels, Western writings, and the Indian tradition. Finally the feasibility of Thomas making such a trip is considered.

\section{Thomas in the Gospels}

The New Testament has not passed down any information regarding the origin, parents, or early life of Thomas. In the list of the twelve disciples, which are arranged in three groups of four each, Thomas occurs in the second group (Matt 10:2-4; Mark 3:6-19; Luke 6:14-16; Acts 1:13). He is linked with Matthew in Matt 10:3 and with Philip in Acts $1: 13 .^{1}$

The Doubter

The name Thomas comes from the Aramaic toma', meaning "twin." Three times John uses the Greek term for twin, didymus $(11: 16 ; 20: 24 ; 21: 27)$. The question as to whose

${ }^{1}$ R. E. Nixon, "Thomas," The Illustrated Bible Dictionary (Wheaton, I11.: Tyndale, 1980), 1558-1559. 
twin he was cannot be answered with certainty. ${ }^{1}$ Some scholars are of the opinion that Thomas resembled Jesus and was thus called "twin."2 "Various traditions (Syriac and Greek) suggest that his personal name was Judas." 3 Raymond Brown holds that Thomas was a Greek name, which, because it resembled the semitic term, was adopted by Jews in the Greek-speaking region. Some would even have us understand John to mean that the man was called Teoma in Aramaic and Didymus in Greek." The term "twin" is explained here in order to prepare for Thomas's "two-minded" or doubting role. In both John 11:16 and 14:5 Thomas exhibits a skeptical attitude. ${ }^{5}$

According to John 11:7, when Jesus said, "Let us go into Judea again," where the Jews were threatening to stone Him, the disciples tried to stop Him from that journey. Immediately Thomas said, "Let us also go, that we may die with him" (vs. 16). The Seventh-day Adventist Bible Commentary explains it thus: "Since his master was bent on

${ }^{1}$ Ibid. 30.

${ }^{2}$ A. F. Klijn, The Acts of Thomas (Leiden: Brill, 1962), ${ }^{3} \mathrm{Nixon}, \quad 1558-1559$.

${ }^{4}$ Raymond E. Brown, John, Anchor Bible, 29 (New York: Doubleday, 1966), 424 .

${ }^{5}$ Ibid. , 1024 . 
going to Bethany, his loyalty led him to follow, though to him, with his mind full of the darkest apprehension, it appeared that they were walking into the jaws of death."

At the last supper, when Jesus let His disciples know that He was soon to leave them, Thomas asked, "Lord, we do not know where thou art going. How are we to know the way there?" (John 14:5). Thomas was, most probably, an eyewitness to the passion and death of Christ. But Thomas was not with the other disciples when Jesus, shortly after His resurrection, appeared to them in the upper room (John 20:24). When the other disciples told him, "We have seen the Lord," he responded: "Until I have seen the mark of the nails on His hands, until I have put my finger into the mark of the nail, and put my hand into His side, you will never make me believe" (John 20:25).

\section{Ellen White comments,}

When Jesus first met the disciples in the upper chamber, Thomas was not with them. He heard the reports of the others, and received abundant proof that Jesus had risen, but gloom and unbelief filled his heart. ${ }^{2}$

"John" [John 11:16], Seventh-day Adventist Bible Commentary, ed. F. D. Nichol (Washington, D.C.: Review and Herald, 1980), 5:1013.

${ }^{2}$ E. G. White, Desire of Ages (Mountain View, Calif.: Pacific Press, 1940), 806. 
The Confession

After eight days (John 20:26) Jesus appeared unto him and said to Thomas, "Reach your finger here and look at my hands: and reach your hand here, and put into My side. Do not be unbelieving, but believing" (John 20:27). ${ }^{1}$ Falling to his knees, Thomas pronounced that brief utterance, "Thou art my Lord and my God," thus confirming the divinity of Christ as God (John 20:28). None of the other apostles had called Christ God. No apostle had ever confessed Him so openly and fully to be Lord; not even Peter in Caesarea Philippi.2 Brown says that in combining the words Kurios and Theos, Thomas was using the Hebrew names for God, Yahweh and Elohim as they are translated by the Septuagint. ${ }^{3}$

The Commission

Jesus appeared a few days later to the apostles on Lake Tiberias; Thomas was also with them. "Simon Peter was there, and with him were Thomas, who is also called Didymus, and Nathaniel, and the sons of Zebedee and two more of his disciples" (John 21:2).

${ }^{1}$ The Bible version used in this dissertation is the New King James.

${ }^{2}$ Herman D'Souza, In the Steps of St. Thomas (Madras: Diocesan Press, 1983), 3 .

${ }^{3}$ Brown, 1047 . 
Before Jesus ascended to heaven He appeared, for the last time, to all eleven disciples (including Thomas) as they sat at the table. Then it was that Christ gave His commission to them:

Go into all the world, and preach the gospel to every creature. He who believes and is baptized will be saved; but he who does not believe will be condemned. (Mark 16:15-16)

Filled with the power of the Holy Spirit, who alighted on the apostles in the shape of fiery tongues (Acts 2:2-4), the apostles dispersed in every direction to preach the "Good News."

\section{Thomas in Other Sources}

The St. Thomas Christians of South India derive their name from Thomas the apostle. The information on Thomas's apostolate in India is founded almost entirely in traditions and legends whose historical validity cannot be verified. Some of these documents provide contradictory information. Contemporary scholarship has not reached consensus on the matter.

On the other hand, the tradition about Thomas as the apostle to India is so strong and so persistent--especially in India--that the lack of standard historical documentation cannot be considered as proof that Thomas never ministered in India. 
An important traditional source of information on Thomas is the apocryphal writing the Acts of Thomas. Other sources are the writings of some Church Fathers. Archaeology has also provided some indirect information.

The Acts of Thomas

Of this writing A. M. Mundadan says:

The Acts of Judas Thomas [were] written in Syriac in the Edessan circle about the turn of the third century A.D. Even though this work has been acknowledged as apocryphal, gnostic in origin, and romantic in style, several scholars find in it a historical nucleus which represents the second century tradition about the apostolate of St. Thomas in India. ${ }^{1}$

While most of the Acts of Thomas is dedicated to narrating the sermons, hymns, prayers, and miracles of Thomas, some biographical information is given. ${ }^{2}$ The story begins with the disciples casting lots for their mission assignments. "India fell by lot to Thomas," who was willing to go anywhere for Jesus--except India. Then we hear of Gundaphorus (also spelled as Gudnaphar) sending Abban (or Habban) to look for a carpenter. The merchant came to the city where Jesus was and was asked by Jesus, "Thou wishest to buy a carpenter?" And on receipt of a positive reply,

${ }^{1}$ A. M. Mundadan, History of Christianity in India, 2 vols. (Bangalore: Theological Publications in India, 1984), $1: 23$.

${ }^{2}$ The Acts of Thomas can be found in Bentley Layton, The Gnostic Scriptures (New York: Doubleday, 1995), 359-415. 
Jesus handed Thomas over to him for a compensation of twenty pieces of silver, the price of a slave. Thomas then accompanied Habban to the capital of Gudnaphar.

On being presented to the king, Thomas agreed to build a royal palace. But the apostle spent the allotted sum on the poor. The disappointed king cast Thomas into prison. While he was lying there, Gad, the king's brother, died and was carried by the angels to heaven. There he was shown the heavenly palaces which Thomas had built by his good works. Gad was restored to life and subsequently both Gudnaphar and Gad were converted.

According to the Acts of Thomas, the apostle preached the gospel throughout India, performing many miracles. The tradition is that he went on to another part of the country, near Madras, at the invitation of its king, Mazdai, and many were converted. At last, by the order of the king, four soldiers stabbed him to death on the top of a hill near the town.

After some time, one of the children of the king was sick and no one could heal him. The king went to the tomb of the apostle and opened it in hopes that the relics might give his son healing. But his bones were found missing, for 
one of the brethren had stolen him away and had taken him to the West. ${ }^{1}$

\section{Archaeological Evidence}

For centuries the name Gudnaphar in the Acts of Thomas was considered mythical. However, the discovery on both sides of the Indus river of coins bearing his name clearly indicates "the existence of a king by the name Gudnaphar who belonged to the Parthian Dynasty that ruled the IndoParthian Kingdom comprising the areas from Afghanistan to Punjab, between 95 B.C. and A.D. 50. The coins show the Greek name of the king Gudnaphar and were minted between A.D. 20 and $45 .^{2}$

A stone tablet, seventeen inches by fourteen and one half inches, found near Peshawar (now in Pakistan) bears an inscription in the Gudnaphar language deciphered as "in the twenty sixth year of the great King Gudnaphar in the year of three and one hundred, in the month Vaisakha, on the fifth day." Historians compute the date of Gudnaphar's accession to the throne at A.D. $45-46 .{ }^{3}$ Gudnaphar died in A.D. 48 and

$$
{ }^{1} \mathrm{KIijn}, 73-78,154 \text {. }
$$

${ }^{2}$ D. Babu Paul, The Syrian Orthodox Christians of St. Thomas (Trivandrum: T. P. Mathew, Samudaya Secretary, 1995), 25 .

$$
{ }^{3} \text { Ibid. , } 25 .
$$


the Indo Parthian Dynasty vanished from history with the Kushan occupation in A.D. $50 .{ }^{1}$

\section{Church Fathers}

In the ancient syriac document, The Teaching of the Apostles, the apostolate of Thomas in India was treated as a fact: "India and all the countries belonging to it and round about it, even to the farthest sea, received the apostle's ordination to the priesthood from Judas Thomas, who was guide and ruler in the church which he had built there, in which he also ministered."2 The Syriac document concerning Abgar and Addacus says, "India was allotted to Thoma." 3

On the other hand, Eusebius did not place Thomas in India. He wrote of Pantaenus (late second century) going to India. There Pantaenus found that "Bartholomew, one of the apostles, had preached to them and left with them the writing of Matthew in the Hebrew language, which they had preserved till that time." 4 Eusebius affirms that Thomas

${ }^{1}$ Ibid., 26.

${ }^{2}$ Alexander Roberts and James Donaldson, eds., AnteNicene Fathers (Grand Rapids: Eerdmans, 1957), 8:671.

${ }^{3}$ Ibid. , $8: 656$.

${ }^{4}$ Eusebius Church History 5.10, The Nicene and PostNicene Fathers, 2 d series, ed. Philip Schaff and Henry Wace (Grand Rapids: Eerdmans, 1961), 1:224-225. 
was a missionary to Parthia. The translator's note points out that Parthia, "in the time of the apostles, was an independent kingdom, extending from the Indus to the Tigris, and from the Caspian Sea to the Persian Gulf." ${ }^{1}$ Klijn points out that the tradition of Thomas in India began after Eusebius. ${ }^{2}$

Ephraem the Syrian (306-373), the noted hymn writer, spoke of the relics of Thomas being returned to Edessa. ${ }^{3}$

F. E. Keay says John Chrysostom (347-407) wrote that "from the earliest days of Christianity, the tomb of St. Thomas was as much venerated in the East as that of St. Peter at Rome." ${ }^{4}$

In answering the reproach of his being a stranger, Gregory Nazianzen (370-390) exclaimed, "What? Were not the apostles strangers? Granting that Judea was the country of Peter, what had Paul in common with the gentiles and Thomas with India?" 5

${ }^{1}$ Eusebius Church History 3.1.11

${ }^{2} \mathrm{Klijn}, 27$.

${ }^{3}$ Ephraem Carmina Nisibis 42, trans. Edmund Beck, Corpus Scriptorum Christianorum Orientalium, 241 (Louvain: Corpusco, 1963), 28.

${ }^{4}$ F. E. Keay, A History of the Syrian Church of India (Madras: ISPCK, 1938), 5.

${ }^{5}$ Ibid. 
Jerome (385-ca. 420) spoke of the mission of Thomas to India as a fact universally known and believed in his time. He mentions Calamina, a town in India, as the place of his martyrdom. ${ }^{1}$

Thomas According to Indian Tradition

Mundadan describes the Indian version of the life of Thomas. According to Indian tradition, Thomas came by sea, and first landed at Cranganore, about the year A.D. 52 . There he converted high caste Hindu families in Cranganore, Palayur, Quilon, and some other places; visited the Coromandel coast, making conversions; then crossed over to China and preached the gospel. ${ }^{2}$

Mundadan goes on to say that "this tradition seems to be made up of elements of the traditions of Malabar, Mylapore or Coromandel and the East Syrian Church." 3 He also observes that Thomas founded seven churches: Cranganore, Kollam, Chayal, Niranam Kokamangalam, Kotta Kayal (Parur), and Palayur. ${ }^{4}$

\footnotetext{
${ }^{1}$ Ibid.

${ }^{2}$ Mundadan, 1:29.

${ }^{3}$ Ibid. , $1: 29$.

${ }^{4}$ Ibid., $1: 30-31$.
} 
Local Traditions

Among these local traditions, the Thomas Rambban Pattu (Song of Thomas), a Kerala wedding song, dates the coming of Thomas to A.D. 50. The first written version of this song comes from 1601 (other sources say 1101); before that it was handed down orally for forty-eight generations. ${ }^{1}$ Better known is Margam Kali Pattu, put into writing in 1732, a song played during the procession in the church festival. It locates Thomas's building of the palace in the Chola Kingdom of South India. ${ }^{2}$

Local traditions hold that Thomas converted many Brahmin families. The St. Thomas Christians still give great honor to these families, and for many centuries the priesthood was confined to some of them. Some of the most important of these families are: Pakalomatam, Sankarapuri, Kalli, Kalikau, Koykkam, Madeipur, Muttodal, Medumpally, Panakkomattom, and Kottakal. ${ }^{3}$ Some of these families have a succession of priests and each of the priests regards himself as the fiftieth or the sixtieth, and so on, of his

${ }^{1}$ Samuel H. Moffett, A History of Christianity in Asia, vol. 1, Beginning to 1500 (Maryknoll, N.Y.: Orbis, 1998), 34. Moffett acknowledges his indebtedness to $A$. $M$. Mundadan, Sixteenth-century Traditions of St. Thomas Christians (Bangalore: Dharmaram College, 1970), 60-63.

${ }^{2}$ Moffett, 34 .

${ }^{3}$ Mundadan, $1: 33$. 
family, counting from the first, believed to have been ordained by Thomas. ${ }^{1}$

While in Kerala Thomas performed many miracles: He brought back to life nineteen dead, drove the devil out of 260 persons, cured 230 lepers, gave sight to 250 blind persons, gave to 220 paralytics the use of their limbs, speech to twenty dumb and restored to health 250 persons given up as hopeless by physicians. In all he converted 17,550 persons of whom 6850 were Brahmins, 2800 Kshatryas, 3750 Vaisyas and 4,250 Sudras. Thus he was able to show the true way of life and salvation to the caste Hindus. ${ }^{2}$

There is a rich tradition related to many of the old churches and communities. The best known of these is that of the Palayur Church, not far from Cranganore. Podipara says:

The Christian church of Palayur stands in a compound where there are seen remnants of Hindu worship such as a tank, a well for drawing water for sacrifice (Poojakinar), the round stone with which this well was covered. The Brahmins in the neighborhood of Palayur even today do not eat or drink anything, nor do they bathe in the Palayur locality which their ancestors cursed and called 'chapakad' (anglicized as chawghat), which means an accursed place. Both the Christian and the Hindu traditions say that when St. Thomas converted some Brahmins of the place, the rest ran away to a nearby locality called Vemmanat saying, 'Iniyathe kuli vemmanat,' meaning the next bath at Vemmanat. This expression has become even a proverb in the language of Malabar. In 1949 the present writer was in Vemmanat and two elderly and respectable high caste Hindu gentlemen, one a Brahmin and the other addicted to the service of the temple of Vemmanat, recounted to him this tradition as current among them. In Palayur there is a compound called Kalath; in Vemmanat there is the Brahmin family of

\footnotetext{
${ }^{1}$ Ibid.
}

${ }^{2}$ Ibid., $1: 31$ 
Kalath which, according to tradition, is one of the Brahmin families that ran away from Palayur to Vemmanat. In Malabar families seldom take their original names from the names of compounds they live in. ${ }^{1}$

Several church historians agree with the view that the apostolate of Thomas was first in North India and then in South India (Kerala) though they differ on the dates. ${ }^{2}$ Mundadan records that "J. N. Farquhar, Adolf Medlycott, Eugene Card, Tisserant, whose principal sources are the 'Acts' and some patristic and medieval references, strongly defend both the North Indian and the South Indian apostolate of St. Thomas." 3

\section{His First Missionary Journey}

Mathew holds the view that "St. Thomas made two trips, the first to North India, which at the time comprised the Indo-Scythia Kingdom and other small protectorates in the northwest." 4 The second trip was to South India.

The name "Thuma Bhagat" that has been found at Tatta on the Indus River in Sindh, where Thomas is still

${ }^{1}$ Placid J. Podipara, The Thomas Christians (Bombay: St. Paul, 1970), 19.

${ }^{2}$ According to D. Babu Paul, Thomas came to North India in A.D. 45-46 (p. 25). P. V. Mathew holds the same view: P. V. Mathew, Acta Indica (Cochin, Kerala: Ladies Service Centre, 1986), 42-43.

${ }^{3}$ Mundadan, $1: 24$.

${ }^{4} \mathrm{P}$. V. Mathew, 32 . 
venerated, may suggest that Thomas worked in North India for some time. ${ }^{1}$ According to Moraes, there are devotees who still practice some Christian rites and possess a book alleged to be the gospel according to st. Matthew. ${ }^{2}$

Moraes holds the view that although Sandaruk, where Habban and Thomas are said to have disembarked, cannot be identified, the two could have entered the friendly Parthian province of Mesopotamia. There they took ship at one of the ports situated at the head of the Persian Gulf and made their way to a port in the Indus Delta (North India) near Sandaruk. ${ }^{3}$

\section{According to Mathew, "Habban the merchant was} conversant with shortcuts and mountain gaps. So he took St. Thomas from Urumiya, negotiating the gap in the Mazandran hills and reached the southwest borders of the Caspian sea. They then crossed the Caspian sea in the ship to the eastern exit at Sandaruk, where they were the guests of honor of the local king. This part is known in Syriac as 'Sandaruk Mahosa' (mahosa means gateway)."4 From Sandaruk, "the slave and the master pursued the royal highway to the palace of

${ }^{1} D^{\prime}$ Souza, 15 .

${ }^{2}$ George Mark Moraes, A History of Christianity in India (Bombay: Manaktala, 1964), 1:45.

${ }^{3}$ Ibid. , $1: 32$.

${ }^{4} \mathrm{P}$. V. Mathew, 34 . 
King Gudnaphar, saved 800 kilometers and reached

'Takashasila' which was one of the Jewish colonies that drew St. Thomas to this place."1

There is no historical evidence of the first missionary journey of Thomas. However, archeological evidence helps historians compute the date of Gudnaphar's accession to the throne as A.D. 45-46.2 This agrees roughly with the traditional time of St. Thomas's arrival in North India and with Mathew's date of around A.D. 46-47. ${ }^{3}$

Return to Jerusalem

The immediate cause of his return to Jerusalem, while St. Thomas was preaching the gospel in the kingdom of Gudnaphar (Vindapharana in sanskrit), was a vision to go to Jerusalem where the blessed mother Mary was about to die. Though he was not able to reach Jerusalem before her death, he saw the angels transporting her body to paradise, while he was himself carried on a cloud to Jerusalem. ${ }^{4}$ In

${ }^{1}$ Ibid.

${ }^{2}$ Paul, 25

${ }^{3} \mathrm{P}$. V. Mathew, 42-43.

${ }^{4}$ E. A. Wallis Budge, Legends of Our Lady Mary (Oxford: Oxford University Press, 1933), 156, 165-166, cited in P. V. Mathew, 42 . 
Jerusalem he offered a burnt offering and spices praying for the blessed mother. The year was A.D. $48 .{ }^{1}$

According to Mathew these accounts show that Thomas returned to Jerusalem from the Kingdom of Gudnaphar and not from Sandaruk as some historians claim. Some have suggested that Thomas returned to Jerusalem to attend the Jerusalem Council in the year A.D. 49-50. At that time "he entrusted the continuation of ministry with deacon Xanthippus of Tashasila." 2

\section{Coming to the Land of Cheras}

On his second missionary journey to India, Thomas is said to have reached the land of the Cheras or the land of the spices, today Cheranad, the vernacular for Kerala. It means the land of coconut trees, whereas in the ancient world Kerala was celebrated as the land of spices. ${ }^{3}$

Historians have different views about the date of Thomas's traditional second trip to India. It must have been considerably later than his return to Jerusalem. ${ }^{4}$

Regarding the route of his journey, some hold that he left from the Mesopotamian Port Pherat Maison (modern

\footnotetext{
${ }^{1} \mathrm{P}$. V. Mathew, 42 .

${ }^{2}$ Ibid., 43.

${ }^{3}$ Ibid., 48.

${ }^{4}$ Ibid.
} 
Basrah) through the Persian Gulf and crossed the Gulf of Oman (Hormuz Strait) to reach the island of Socotra. ${ }^{1}$ Traveling eastward, he finally landed in Muziris, the chief port in Cheranad, which was the first emporium of India and was the celebrated port and capital of the Chera Kingdom, one of the three Tamil kingdoms.

This route from Socotra to Muziris had become quite popular since Hippalus had discovered that taking "advantage of the southwest sea breeze," sailors could travel from Socotra to Cheranadu in forty days. ${ }^{2}$ Pylee also holds that mariners traveled from the mouth of the Arabian Gulf across the ocean and let the western monsoon carry them to Muziris (Cranganore) on the Malabar coast. ${ }^{3}$ Mingana says that Thomas started on his second voyage from "the port of Kharax-Spasini, that is situated at the mouth of the Persian Gulf" and reached Muziris (Cranganore) in the year A.D. 52.

${ }^{1}$ Ibid.

${ }^{2}$ Ibid.

${ }^{3} \mathrm{~L}$. M. Pylee, St. Thomas Christians and the Archdiocese of Verapoly (Ernakulam, Kerala: St. Joseph Industrial School, 1977), 44, 77 .

${ }^{4} \mathrm{~A}$. Mingana, "The Early Spread of Christianity in India," The Bulletin of the John Rylands Library 10 (July 1926): 5 . 


\section{His Converts}

Some church historians who write about Christianity in India hold the view that Thomas preached the gospel to the settled Jews first and then to the Hindus. A. K. Thomas observes that "it was in fact the Jewish settlement in Muziris that attracted St. Thomas to the port." ${ }^{\text {Though the }}$ first converts to Christianity are believed to have been Jews, many among the other converts were high caste Brahmins (Namboothiris) and Nairs. ${ }^{2}$ D. Babu Paul reminds us that the apostles thought it their duty to acquaint the Jews of the dispersion of this long-awaited national event. However, "the Apostle Thomas did not confine his missionary activities to the Jews, but preached to the indigenous population also." 3

It is a historical fact that Jewish colonies were found all over the coast of Malabar in the first century A.D. These colonies would have attracted Thomas the apostle

${ }^{1}$ A. K. Thomas, The Christians of Kerala (Kottyayam, Kerala: D. C. Offset, 1993), 18.

${ }^{2}$ See also P. Thomas, Churches in India (New Delhi: Publication Division, Ministry of Information and Broadcasting, Government of India, 1990), 2; M. O. Joseph, Kerala Kristhi Yanikal [History of Christians in Kerala] (Cochin, Kerala: LFI, 1972), 59; C. V. Cherian, A History of Christianity in India (Kottayam, Kerala: Historical society, 1973), 36; Thomas A. Timberg, Jews in India (Sabidabad, Uttar Pradesh: Vikas, 1986), 128 .

$$
{ }^{3} \text { Paul, } 27 .
$$


to Kerala. Mundadan affirms that among these Jewish colonies he preached the gospel and established the first Christian churches. ${ }^{1}$

Among the thousands of Jews and Hindus who are said to have been converted, the apostle appointed future leaders of the church, he ordained priests, and consecrated bishops. "Kepa and Paul are said to have been consecrated bishops. Kepa belonged to the royal family of Cranganore and he was sent over to Kerala."2

The Marriage of the Princess of Cranganore The apostolate of Thomas in Kerala was introduced through signs and wonders. The day Thomas arrived in Kerala was the day of the marriage of the daughter of the king of Cranganore. ${ }^{3}$ All the people were invited to the royal marriage. Thinking that it would make the king unhappy if he did not attend, Thomas decided to attend the marriage. Though a delicious menu was served, the apostle did not eat but was gloomy because he had come for something greater than food. Thinking that Thomas looked down on the feast in which he did not take part, the king's servant slapped his

${ }^{1}$ Mundadan, 19.

${ }^{2}$ Ibid., 31.

${ }^{3}$ This story corresponds to the first act of the Acts of Thomas. 
cheek. He is said to have said in Hebrew that the hand which slapped him would be dragged along by dogs. This was overheard by a Jewish girl who was singing there. The king's servant went out to fetch water and a tiger came, attacked him, and tore off his hand. A black dog carried off his right hand, which he had raised against Thomas, and brought it into the banquet hall. When this happened the people there understood that Thomas had supernatural power. He healed the hand of the king's servant and the people who were there became more sure about his supernatural power to perform miracles. This was God's purpose for the mission.' The king then asked the apostle to bless his daughter and son-in-law. Thomas did so. By a miracle the Lord attracted the couple to eternal matters rather than worldly and physical passions. The King ordered Thomas's arrest, to put him in jail. But by that time Thomas had already left Kerala for Cholanad. Subsequently, not only this couple, but the king and many of his other subjects, believed in Jesus and accepted Christianity.

The apostle stayed at Cholanad only a few days, then returned to Cranganore and stayed one and a half years preaching the gospel. "About three thousand unbelievers and ${ }^{1}$ Joseph, 50; Klijn, 66-72. 
forty Jews became Christians there and he established a church for them."1

Kurakeni and the Church of Paravoor

From Cranganore the apostle is said to have gone to Kurakeni (Quilon), where many were converted through preaching and miracles. Next he proceeded to Niranam, north of Quilon, which was a Jewish colony at that time. Many Jews and Brahmins were converted during his stay of more than one year.

Tradition says he next went to Paravoor, which was a Brahmin village as well as a center for the Jews. The Brahmins in that place were angry with him because so many were converted to Christianity. But the Lord, by a miracle, helped him to establish a church there. A temple was converted into a church. According to legend, Brahmin families such as Manavassery, Chempakassery, Kanjirakattu, Kunnappally, Vazhuppally, Vezhappally, and Vanganadu accepted Christianity. ${ }^{2}$

The Water at Palayur

From Paravoor the apostle next went to Palayur, another Jewish settlement. Palayur also was a Brahmin

\footnotetext{
${ }^{1}$ Ibid., 51.

${ }^{2}$ Ibid., 51-52.
} 
center. Today it is a small village on the outskirts of the town called Chavakkad. It was one of the four ancient Jewish settlements in India. There was a flourishing market, the name of which remains even today: Jootha Bazaar. ${ }^{1}$ It is said that there were about 70,000 to 80,000 Jews there. There Thomas is said to have converted a group of Jews and a much larger group of Nambudiris to Christianity. ${ }^{2}$

When he reached Palayur, the Brahmins were bathing in the pond and were throwing water up as a form of worship, to quench the thirst of their ancestors. "What are you doing?" the apostle asked. "But why is the water not staying up? It is not accepted by the ancestors, hence it is coming down." They replied that such was the character of the water and it was not possible to keep it up. The apostle said that in God's name he could keep the water up so it would not come down. "Then we want to see it," said the Brahmins. The apostle made an agreement with the Brahmins that they would accept the God of the apostle if the water stayed up, and if not they would retain their own religion. The apostle got into the pond, took the water in his hand and threw it up and it stayed there. A mark was seen where

${ }^{1}$ Timberg, 128 .

${ }^{2}$ Ibid. 
the water was taken, but the apostle's feet and clothes were not wet. Those who witnessed this miracle were baptized by immersion by the apostle. Those who did not believe in Christ "cursed the place and announced that the 'next bath would be at Venmanattu' and left the place."

The Log at Mylapore

The apostle Thomas is said to have performed many miracles at Mylapore. One of the most important had to do with a log which the king and his subjects could not pull ashore. Knowing this, the apostle went to the coast and asked if they would allow him to build a house for the Lord with that log. Then he would be able to bring the log to the desired place. The king consented for the apostle to build a church with that log wherever he would drop it. The apostle went up to the log and drew a symbol of the cross on it. He then removed his belt and tied it to the $\log$ and pulled it up to the house where the king's chief minister lived. The apostle then began to build the church according to the king's promise. ${ }^{2}$

The minister could not tolerate the building of the church near his house. He devised a plan to get Thomas in trouble. He killed his own son and charged Thomas with

\footnotetext{
${ }^{1}$ See p. 17.

2Joseph, 54.
} 
murder. In order to prove his innocence, Thomas raised the son from the dead and told the child to tell the truth. The child revealed that his own father had killed him. Not only that, the child also said that he had seen the heavenly bliss and had no desire to live on this earth. The apostle baptized the child who promptly died again. The king was wonderstruck and gave special permission for the construction of the church building. Thomas gave the workers sawdust for their wages, and according to the legend that sawdust became gold coins. ${ }^{1}$

\section{His Martyrdom}

At Mylapore Thomas used to go for meditation to a secluded place called "Little Mount." His enemies knew that he meditated there in a cave. One day a group of Brahmins stopped him on the way and told him that those who did not bow down to the jungle there, would not be allowed to pass through. The apostle replied that if he bowed down, the jungle would be burned. The men challenged him to do so. Immediately the apostle turned to the jungle and drew the symbol of a cross and suddenly the jungle caught on fire. The Brahmins only became angrier. After the incident he went on to the cave for his meditation as usual. While he was in prayer a priest of King Mahadevan pierced him from

$$
{ }^{1} \text { Ibid., } 56-57
$$


behind with a lance. Mortally wounded, he moved to the big mountain where he used to pray, embraced a stone cross there, and shortly passed away. ${ }^{1}$

Hearing the news, King Paul, the metropolitan, priests, and Kepa metran from Kerala, along with the priests and believers, all rushed to the spot. They buried him in the church at Mylapore. Today the mountain area is known as St. Thomas Mount where the San Thome Basilica is built. It is believed that his martyrdom took place on 3 July, A.D. $72 .^{2}$ However, Clement of Alexandria affirmed that, according to Heracleon, Thomas died a natural death. ${ }^{3}$

\section{Historical Factors to Be Considered}

Certain historical facts contribute to the feasibility of Thomas's trip and ministry in Kerala. First was the existence of an active sea route; second was the presence of Jews in Kerala.

\section{The Sea Route}

India was known to the world centuries before Christianity came to India. Travel routes were clearly established and trade was plentiful.

\footnotetext{
${ }^{1}$ Ibid., 60-61.

${ }^{2}$ Ibid., 62 .

${ }^{3} \mathrm{Klijn}, 27$.
} 
There were three main routes between India and the Western world. First, a route existed from the mouth of the Indus to the mouth of the Euphrates. From there roads led to Antioch and the Levantine ports. Second, there was an overland route over the mountains to the Balkans and from there to the Caspian Sea, entirely by land. A third route went from India to the Red Sea, thence by road to the Nile and from there to Alexandria, a town which strabo says had been founded to capture the Indian trade for Rome. This last route was the usual one in the first century. ${ }^{\text {I }}$

The discovery by Hippalus, an Egyptian pilot, of the monsoon winds blowing regularly across the Indian Ocean gave an impetus to reach Cranganore in a short time and return by the same route. ${ }^{2}$

South India, particularly Kerala, was famous for its spices which attracted foreign trade. Cherian points out that the "Arabs, the Assyrians, the Babylonians, the Phoenicians, the Israelites, the Greeks, the Romans and the Chinese were among the foreign people who had contacts with the Kerala coast in the ancient period." 3

${ }^{1} \mathrm{~L}$. W. Brown, The Indian Christians of St. Thomas (Cambridge: Cambridge University Press, 1956), 59.

${ }^{2}$ Joseph, 34 .

${ }^{3} \mathrm{C}$. V. Cherian, 27. 
Greeks and Romans of the first century carried on extensive trade with Kerala. Ginger, turmeric, cardamom, cinnamon, and pepper are among the spices traded. This trade brought foreign immigrants to Kerala. ${ }^{1}$

\section{Presence of Jews in Kerala}

Both secular and religious historians agree that Kerala had a Jewish presence from time immemorial. The first reference to Jews in connection with India is given in the Bible. The book of Esther refers to events which occurred during the fifth century B.C. The Empire of Ahasuerus (Artaxerxes of History) is said to have extended from Ethiopia to India (Esth 1:1, 8, 9) and to have contained 127 provinces (Esth 8:9; 9:30). Letters involving the Jews were sent to all these provinces, suggesting the presence of Jews in them all. History confirms that the Persian empire extended from the Mediterranean to the Indus. ${ }^{2}$

The Coming of the Jews to Kerala

In keeping with the evident Jewish dispersion, tradition, as well as historians, has looked for an appropriate time for their transfer to Kerala. Padmanabha

\footnotetext{
${ }^{1}$ Mundadan, $1: 21$.
}

'Joseph S. Exell, "Esther," Biblical Illustrator (Grand Rapids: Baker, n.d.). 
Menon suggests that the "first Jews who arrived on the Malabar coast came in Solomon's fleet of merchants." 1 Another suggested date is after the conquest of Judea by Nebuchadnezzar in 586 B.C. ${ }^{2}$ Logan suggests that the Jews on the Malabar coast might have settled there after escaping from Cyrus in the sixth century B.C. ${ }^{3}$

King Solomon's fleet is said to have sailed every three years, to procure gold, silver, ivory, apes, and peacocks. Although the Bible (1 Kgs 10:22) does not say the ship traveled to India, Pillai notes that these products would have been acquired in south India, where trading Jews later settled. ${ }^{4}$

One of the traditions of the Kerala Jews says that the colony came from Jerusalem before the destruction of the second temple in the year A.D. 68. Some ten thousand Jews, men and women, are said to have come to Malabar and settled at Cranganore, Palayur, Mala, Chawghat, and Pullut. Of these, three-fourths remained at Cranganore, then called

${ }^{1} \mathrm{~K}$. P. Padmanabha Menon, History of Kerala, 3 vols. (New Delhi: Asian Educational Service, 1984), 1:298.

${ }^{2}$ P. V. Mathew, 62 .

${ }^{3}$ William Logan, Malabar, 2 vols. (New Delhi: Asian Educational Service, 1989), 1:247.

${ }^{4}$ K. K. Pillai, South Indian History (Trichur, Kerala: Current Books, 1960), 38 . 
Mahadever Pattanam (great city of God). ${ }^{1}$ A. S. Menon says that the Jewish immigration of A.D. 68 to Kerala was the direct effect of early commercial contact with Israel. ${ }^{2}$

The Number of Jews in Kerala

in the First Century

There is dispute over the number of Jews in Malabar.

The original settlement is said to have consisted of 10,000 men and women. But writers such as Buchanan in the beginning of last century "computed their number at 16,000."3 Alexander Hamilton speaks of there being 4,000 families. ${ }^{4}$

Benjamin Israel says that 70,000 to 80,000 Jews migrated to Malabar in the year A.D. 370,5 during the reign of Cheraman Perumal. ${ }^{6}$ Cheraman Perumal showed his deference

${ }^{1}$ K. P. Menon, 2:504-505.

${ }^{2}$ A. Sreedhara Menon, Survey of Kerala History (Madras: S. Viswanathan, 1994), 20.

${ }^{3}$ K. P. Menon, $2: 526$.

${ }^{4}$ Ibid.

${ }^{5} \mathrm{~J}$. Benjamin Israel, The Bene Israel of India (Bombay: Orient Longman, 1984), 52.

6 "There were twenty-five Perumals who ruled for 212 years, i.e., from 216 A.D. to 428 A.D. . . . The first and last Perumals bear one common name, Cheraman Perumal, though they are also specifically known as Cheraman Keralan and Bhaskara Ravi Varma. . . According to other accounts, Cheraman Perumal was more a title than a name and was applied to all the Perumals alike." N. Nagam Aiya, The Travancore State Manual, vol. 1 (Madras: Educational 
to the Jews by giving to Joseph Rabban the city of Cranganore in perpetual possession. ${ }^{1}$

\section{Evidences of Their Presence}

There is no Jewish colony in Malabar today. There is, however, a "Jews' Hill" at Chawghat and a "Jew's Tank" at Madayi .

In the Jewish Synagogue at Mattamchery, Cochin, Kerala, on the right side of the synagogue there is a series of plaques on which the story of the arrival and settlement of a Jewish kingdom is narrated in pictures. These records helped historians to reconstruct the history of the Jewish settlement on the Malabar Coast. Each plaque has a description written in English.

No. 1. There was trade between king Solomon's Palestine (992-952 B.C.) and the Malabar coast. The Biblical name for India was "Odhu." Teak, Ivory, spices, and peacocks were exported to Palestine.

No. 2. The destruction of the second temple in 70 C.E. by the Romans and the consequent dispersal of the Jews to the four corners of the Earth from Palestine.

No. 3. Landing of the Jews at Shingly (Cranganore) in 72 C.E.

No. 4. The king receives them at Cranganore port.

No. 5. Joseph Rabban, the leader of the Jews, receives the copper plates from Cheraman Perumal. He

Services, 1989), 224.

${ }^{1}$ Israel, 320. 
was made prince of Anjuvanam and thus a Jewish kingdom was established at Cranganore in 379 C.E.

The flooring of the synagogue is of blue and white china tiles. The women's gallery is screened from the main part of the synagogue, around which are benches for men. Inside the gateway, through the first courtyard, on the wall is the plaque which shows Joseph Rabban receiving the Jewish copper plate. On the floor below, the worshipers leave their shoes and enter the building. In the synagogue the appointed member of the community opens the most holy place and shows the Torah and then explains the historical background.

Still today the Jewish street at Mattanchery and the synagogue are tourist attractions. Israeli President Ezer Weizman visited this synagogue on January 3, 1997. He said "the Malabar coast which claims Jewish relationship since the time of King Solomon has been a refuge and safe place for the Jews for centuries, while they were persecuted everywhere." 1

\section{A Possible Essene Connection}

According to P. V. Mathew, the body of the early

\footnotetext{
${ }^{1}$ Ezer Weizman, "The Jewish President's Visit,"
} Malayalam Manorama Daily Newspaper, January 3, 1997, 4. 
Christian converts among the Jews was largely Essene. ${ }^{1}$

These Essenes could have migrated between A.D. 68 and 70 due to the fact that in the first century Cranganore was a famous port in India, with "120 ships every year" coming there, and making it easy for the apostle to bring them to Kerala as they were to leave their own land. 2

Mathew observes that

some of the Essenians and other Jews who arrived in Muziris in A.D. 68 settled down in Palayur,

${ }^{1}$ Though they are not mentioned in the Scriptures, with varying degrees of detail and emphasis, "the Essenes are mentioned by Philo, Pliny, Josephus, Hippolytus, Solinus, Eusebius, and Epiphanius. Pliny and Solinus are the most important sources of the Essene community on the shores of Dead Sea." Matthew Black, The Scrolls and Christianity (London: SPCK, 1969), 11.

The Essenes were a sect of "Jews during the Hasmonean and Roman periods of Jewish history (150 B.C.E. -74 C.E.) This group was noted for its piety and distinctive theology." Lawrence H. Schaffman, "Essenes," Encyclopedia of Religion, ed. Mircea Eliade (1987), 5:164. They were "strict observers of the Sabbath." Jean Danielou, The Dead Sea Scrolls and Primitive Christianity (London: Omega, 1958), 34, 123. They expected the appearance of a Messianic figure who would arise to gather the scattered hosts of Israel together to defeat the enemies and to inaugurate the age of God. Williston Walker, A History of the Christian Church (New York: Charles Scribner's Sons, 1959), 16.

The community of Essenes existed until A.D. 70. After the fall of Jerusalem in A.D. 70 Antioch became "the center of Aramaic Christianity and gave it its Essenian color." Danielou, 118. Danielou suggests that the Christianity which St. Paul found in Damascus was that of converted Essenes. Ibid., 102.

During the Jewish revolt, the survivors of the Essene community hid their sacred books in caves and escaped to different parts of the world. Ibid., 90.

${ }^{2}$ James Aerthayil, The Spiritual Heritage of the St. Thomas Christians (Bangalore: Dharmaram, 1982), 120. 
Chatlukulangara and neighboring places. The Jews' $\mathrm{Hill}$ in Palayur suggests their residence in the past, but the Essenians who were converted to Christianity by st. Thomas elected to stay on a neighboring hill, Chattukulangara. Here St. Thomas arranged to erect a chapel in the name of the blessed Mother which is the Arthat Kunnamkulam church today at Trichur, Kerala. ${ }^{1}$

He goes on to say that "the Pulikkottil family that traditionally provided priests to the Arthat, Kunnamkulam church was one of the Jewish Essene families." 2

In addition, Manimekalai, the Tamil epic written in the third century, says that the Jews, whom it calls Issanis (Essenes), were living in Kanjeepuram, the capital of Tondinad. ${ }^{3}$

\footnotetext{
${ }^{1}$ P. V. Mathew, 66-67.
}

${ }^{2}$ Ibid., 71

${ }^{3}$ Cattanar Cittalai, Manimekalai [Tamil Epic] (Madras: Parinilayam, 1963), 106, 311-312. 
CHAPTER III

LEGACY OF ST. THOMAS

According to tradition, the legacy of Thomas was the Christian community in Kerala. The fortunes of this group of Christians fall into two distinct stages: until the coming of the Portuguese in 1500, and after the arrival of the Roman Catholic Portuguese.

\section{St. Thomas Christians until 1500}

There are few records about the St. Thomas Christians before the sixteenth century. The reasons are many. Not many people knew how to read and write. Paper and ink were not available. People wrote with nails on palm leaves, but even this was not common. ${ }^{1}$ In addition, almost all the local accounts, especially the syriac books, perished in the persecutions carried out by the Portuguese before, during, and after the synod of Diamper in 1599. The only way to find the legacy of Thomas in India is to study the record penned by the Portuguese. They seem to have searched deeply

${ }^{1}$ P. M. Mathew, Kananaya Sabha Charithram [History of the Kananay Church] (Chingavanam, Kerala: Kananaya, 1996), 1 . 
into the Iife, customs, and traditions of the community. They wrote about the oral traditions, folk songs, written accounts, and syriac books which the community then had in its possession. ${ }^{1}$

\section{St. Thomas Christians in the Second through Fourth Centuries}

The church traditionally established by Thomas in the first century grew strong in the succeeding centuries. The structure of the local community and the spirit of toleration shown by the local rulers were instrumental in shaping the Christian church on Indian soil.

To a great extent, the St. Thomas Christians were not influenced by pagan philosophies which were prevalent in the church in other parts of the world in those centuries. A.

T. Philip observes that

despite the influence of Hinduism on the social life of Christians (with particular reference to syrian Christians of Kerala) there never took place a synthesis of Christianity and Hindu philosophy. This was contrary to what has happened in the Greco-Roman world (Pagan) in the first four centuries of Christianity. ${ }^{2}$

Christianity in Kerala was inseparably connected with Judaism. In the words of D'Orsey, "Thomas preached to them

${ }^{1}$ E. R. Hambye and C. M. I. Perumalil, Christianity in India: A History in Ecumenical Perspective (Bangalore: St. Paul, 1972), 23-24.

${ }^{2}$ A. T. Philip, The Mar Thoma Church and Kerala Society (Trivandrum: Juhanon Mar Thoma Study Centre, 1991), 12. 
(Jews) the Gospel, converted them, and changed their synagogue into a Christian church. This was the cradle of Christianity in India." At the same time Christianity adapted to the local situation. Ferguson writes:

There is hardly any reasonable doubt, therefore, that the Christian community of India in about A.D. 354 was an indigenous community, not much in touch with the practice prevalent in the Greco-Roman churches and somewhat similar to the East Syrian church before the time of the Catholicos Papa. ${ }^{2}$

Joseph points out that they practiced an oriental form of worship until the sixteenth century, together with the disciplinary and social dimensions of the local culture. ${ }^{3}$ The Scriptures they had were written in syriac and were not translated into the local languages. ${ }^{4}$

The St. Thomas Christians were far from the religious persecution faced by Christians elsewhere in the world. ${ }^{5}$ They were firm in their faith. They seldom tasted meat or wine, and lived almost entirely on a simple diet. "They did not use images in their churches, and they were particular

${ }^{1} J$. D. D'Orsey, Portuguese Discoveries, Dependences, and Mission in Asia and Africa (London: W. H. Allen, 1893), 64 .

${ }^{2}$ Everett Ferguson, Backgrounds of Early Christianity (Grand Rapids: Eerdmans, 1993), 459.

${ }^{3}$ Joseph, 114-121.

${ }^{4}$ Ibid., 121

${ }^{5}$ Aerthayil, 32 . 
and devout in their sabbath attendance and at communion, but not as a matter of obligation." ${ }^{1}$ Their priests were allowed to marry. They were lovers of fasts and of long sermons. They went to church only with washed bodies and care was taken not to be polluted by others' touch. They attended church only on Saturday evening and Sunday morning; on the other days they did not enter the church.

At worship they recited the psalms and lessons in "Chaldean" or East Syriac." Four lessons of the Bible were always read in their liturgy, following the Hebrew canon, from the Pentateuch and from the prophets. This was a heritage received from the Jewish synagogue. ${ }^{3}$. Podipara says that their worship was influenced by Judaism. ${ }^{4}$

Mathew says that "the Christians of Malabar and the immigrants [Kananaya Christians] both accepted the same faith and followed the same liturgy." 5 "Even Thomas of

${ }^{1} \mathrm{~J}$. Stewart, Nestorian Missionary Enterprise (Trichur, Kerala: Mar Narsai, 1961), 125-126.

${ }^{2}$ A. M. Mundadan, St. Thomas Christians, $1498-1552$ (Bangalore: Charmaram College, 1967), 198.

${ }^{3}$ Vander Pelog, The Christians of St. Thomas in South India and Their Manuscripts (Bangalore: Dharmaram, 1983), 50-51.

${ }^{4}$ Placid J. Podipara, The Malabar Christians (Allepey, Kerala: Prakasam, 1972), 64, 104 .

${ }^{5}$ P. M. Mathew, 214 . 
Cana did not make any change." ${ }^{1}$

Thomas of Cana

The record of the visit of David, Bishop of Basra, to India around the year 300 and the fact that John of Persia represented the church in India at the Nicean Council in 325 seem to indicate a well-ordered church in Kerala in the early fourth century. ${ }^{2}$

However, other writers indicate that after the death of Thomas, the Malabar church was left without a leader. For ninety-three years there were no priests at all. Around the close of the second century a pagan magician by the name of Manikkabasher (Manikkavachakar) came to Mylapore and led many to his side through miracles. The Mylapore faithful fled to Malabar as refugees and were accepted by the believers there. Only 160 families remained faithful. Later, due to the lack of priests and rivalry among the families, many fell into apostasy and only sixty-four families continued in the true faith. ${ }^{3}$

${ }^{1}$ Timberg, 184 .

${ }^{2}$ C. B. Firth, An Introduction to Indian Church History (Madras: Christian Literature Society, 1983), 20-21.

${ }^{3}$ George Menacherry, The St. Thomas Christian Encyclopedia of India, 2 vols. (Trichur, Kerala: St. Thomas Christian Encyclopedia of India, 1982), 1:7. 
In a night vision, the Metropolitan of Edessa, Mar Joseph, saw the pathetic condition of the Malabar Christians. The next day he narrated his vision to the Catholicos of the East. Hearing this, the Catholicos sent messengers to all churches and towns under his jurisdiction and summoned all the Christians before him. The Catholicos explained the vision. Hearing the vision, one of the faithful, a "certain Thomas of Cana," responded that he had heard about Malabar and India from strangers. The Catholicos asked him to visit Malabar and report on the matter. Accordingly, around the year A.D. 300 Thomas set sail and arrived in Malankara, where he met the St. Thomas Christians. They narrated everything to him. He consoled them, returned to the Catholicos, and explained the need of the brethren of Malabar. The Catholicos expressed the desire to sacrifice even his own life for the Christians of Malabar.' Mingana reports that

by order of the king and the bishop three hundred and thirty-six families composed of children and grown up people, clerics, men and women, came to India under the leadership of Thomas the Canaanite from Canaan, which is Jerusalem. They landed at Malankara in the year A.D. $345 .{ }^{2}$

${ }^{1}$ David Daniel, The Orthodox Church of India (Delhi: Printaid, 1986), 37 .

${ }^{2}$ Mingana, 49 . 
At this time Emperor Cheraman Perumal was ruling, so the newcomers went to him and informed him about the cause of their coming. The king was pleased and gave them land in the territory of Cranganore (Muziris) to build churches, houses, and shops. The town came to be called Mahadevar Pattanam (City of the Great God). The Christians were also given royal privileges, known as the "Seventy-two Privileges," giving them permission to carry on their trade throughout the country. These permissions were written on copper plates. ${ }^{1}$

There are differences of opinion about the origin of the Canaanite Christians. M. K. Thomas, a present-day member of the Canaanite community in Trivandrum, claims "both an Israelite and a Judaic source" for their ancestors. Based upon local tradition and theological sources, he expounds the theory that the Canaanites were early JudeoChristians who believed in Jesus as the Messiah, and were known as Nazaranis. These Nazaranis, who reached Kerala in A.D. 345, are claimed to be the remnant of the Nazaranis who vanished from the Middle East, that is, the Jerusalem community settled in Edessa. ${ }^{2}$

${ }^{1}$ Scaria Zacharia, The Acts and Decrees of the Synod of Diamper 1599 (Edamattam, Kerala: Indian Institute of Christian Studies, 1994), 42-43.

${ }^{2}$ M. K. Thomas, cited in Timberg, 183-185. 
Timberg observes:

Even the Christians who migrated to Kerala with the merchant Thomas of Cana were Jewish Christians. . . These early Judeo-Christians who believed in Jesus as the Messiah for the Jews, and abided by the Mosaic law, migrated from Palestine to Syria and settled in Kerala, thereafter mingling with the local St. Thomas Christians. ${ }^{1}$

The newcomers apparently merged with the old Christians, and the St. Thomas Christians in Kerala were reinforced. Converts were gained from Jews, Brahmins, Vaishiyas, Sudras, and Shatriyas. They lived in unity and integrity and followed the faith and practice which they had received, according to tradition, from the apostle Thomas. ${ }^{2}$ From that time, the Church of St. Thomas spread without hindrance "until the coming of the Portuguese in the sixteenth century." 3

Privileges of Jews and Christians

Privileges were given to both Jews and Christians.

About 379 A. D. the ruling king (Perumal) Bhaskara Ravi Varma granted valued privileges to the Jews. Their leader Joseph Rabban was brought to the rank of nobility and was

${ }^{1}$ Timberg, 183-184.

${ }^{2}$ Ibid. , 184 .

${ }^{3}$ P. V. Mathew, 28. 
allowed to exercise full jurisdiction in the community. This points to their attainment, power, and prosperity. ${ }^{1}$

At this time, Joseph Rabban was given the rulership of Anjuvanam, along with seventy-two rights such as riding elephants, receiving tribute from subordinate land holders, and the revenue of Anjuvanam. ${ }^{2}$ He could also use light by day, the spreading cloth, the litter, the umbrella, the drum beaten with two sticks, ornamental arches, and garlands. Though there are disputes over the date of this grant, the Jewish record says that it happened in A.D. $379 .^{3}$

The Christians were given the same number of privileges by Cheraman Perumal in 345 A.D. ${ }^{4}$ In Iravi Korttan's plate, sixteen privileges are mentioned. K. E. Koshy lists all seventy-two privileges. ${ }^{5}$ Some of these include: (1) At the time of marriage the Pantal (pavilion) might be supported by a pillar holding up the ridge pole, as

${ }^{1}$ K. P. Menon, 2:506.

${ }^{2}$ This information comes from two copper plates from the fourth century. One is presently at the Marthomite headquarters at Thiruvalla; the other is in the British Museum. Details regarding the plate can be found in $K$. N. Daniel, A Brief Sketch of the Church of St. Thomas in Malabar and the Syrian Copper Plate (Kottayam, Kerala: CMS, 1933); see also D. Daniel, 39-46.

${ }^{3}$ K. P. Menon, 2:514.

${ }^{4}$ K. N. Daniel, 11 .

${ }^{5} \mathrm{~K}$. E. Koshy, History of St. Thomas (Thiruvalla, Kerala: MGM, 1954), 54 . 
with Brahmins; (2) silk umbrellas and other special poles might be carried during processions; (3) men might walk with wooden swords and shields covered with leopard skins; (4) triumphal arches could be erected on the route and lamps lit outside the houses; (5) the bridegroom could ride an elephant; (6) certain honorific titles were allowed. ${ }^{1}$

The writings of the two copper plates presented to the Jews and the Christians in 1320 by Ayyan Kurakkeni Chera, king of Cranganore, show the unity and the privileges of the Jews and Christians at that time:

The army of 600 , and the Jews and the Christians of Manigonmam trade guild shall protect the church and the land granted to it. The Jews and the Manigramites [Christians] shall act as laid down in this copper plate deed as long as the earth, the moon and the sun will endure. . . . The custom duty collected each day shall be in the custody of the Jews and the Manigramite Christians. When land is sold within the four walls of the city, the king shall take his tithe, while the chief tithe shall be taken by the Jews and the Manigramites. ${ }^{2}$

These gifts were given to these communities as a reward for their protection of the Tarisa church and the land given to it. The city of Manigramam was founded by

${ }^{1}$ Tharakan, Muthalali, and Panikkar were titles of honor granted by the rajas; these are still continued. Nasrani Mappila, a title of honor, was originally granted by the rajas and even today the Christians of Kerala are known by the nickname "Nazaranis." L. W. Brown, 170.

${ }^{2}$ K. N. Daniel, 11, 19. 
Maruvan Sabriso, who was a Jewish Christian. ${ }^{1}$ Logan observes that "the Jewish and Christian organizations were given privileges similar to those of Nayars."2 Their head men, Joseph Rabban and Iravi Corttan, as Thomas of Cana was called, were given hereditary rank equal to that of a chieftain. ${ }^{3}$ Rae holds that "both the Jews and the Christians were given equal position" ${ }^{4}$ and there was no antagonism between the local Jews and the Christians, unlike conditions in Europe. ${ }^{5}$

The Jews and the Christians were not only protected by the king, but also had a military force of their own, which was composed chiefly of Shanars, the caste that cultivated the palm trees. They and the Brahmins were the only inhabitants of the country who were permitted to have enclosures in front of their houses. ${ }^{6}$

I'Ibid., 9.

${ }^{2} \operatorname{Logan}, 1: 267$.

${ }^{3}$ Ibid.

${ }^{4}$ George Milne Rae, The Syrian Church in India (London: William Blackwood and Sons, 1892), 161.

${ }^{5}$ Israel, 31.

${ }^{6}$ Ibid. 
Relations with the West

Although India was isolated from the Roman Catholic Church until the end of the fifteenth century, two connections with the West remained: the syriac and the Nestorian.

\section{The Syriac Connection}

The Church of the East used Syriac in its liturgy and writings. This language is generally accepted as being "substantially the same as the Aramaic spoken by our Lord and the Apostles." I It would have been, therefore, the language of Thomas.

The Indian Christians used Syriac in their liturgy. They had a "special devotion for the Syriac Ianguage because it was the language of Jesus and their apostle Thomas." 2 They also had Scriptures in Syriac. ${ }^{3}$

According to Mingana, in the fifth century the st. Thomas Christians sent their priests to be educated at the best schools of East Syria. There they also assisted the

${ }^{1}$ Aerthayil, 35.

${ }^{2}$ Ibid., 32 .

${ }^{3} \mathrm{~V}$. K. George, The Holy Church of the East and Mar Nestorius (Trichur, Kerala: Mar Narsai, 1959), 10-11. 
doctors of that school in their revision of the ancient Syriac translation of the Pauline epistles. ${ }^{1}$

Given the use of Syriac for the liturgy and Scriptures, and the education of Indian priests in educational centers of the Church of the East, one would assume that the two groups shared doctrines also. Philip Schaff points out that the Eastern Church marked "the seventh day of the week (excepting only the Easter Sabbath) by omitting fasting," in opposition to the Western Church that made Saturday a fast day. ${ }^{2}$ This would indicate a special veneration of the seventh day. It would be expected that the Christians of Kerala would have done the same.

Mingana rightly concludes that

any attempt to speak of early Christianity in India as different from the East Syrian church is, in our judgment, bound to fail. Christianity in India constituted an integral part of the church that began to develop vigorously toward the end of the first century in the Tigris valley. ${ }^{3}$

${ }^{1}$ Mingana, 27.

${ }^{2}$ Philip Schaff, History of the Christian Church, vol. 1, Ante-Nicene Christianity (Edinburgh: T. \& T. Clark, 1893), 205.

${ }^{3}$ Mingana, 8 . 


\section{The Nestorian Connection}

Church historians hold different views regarding the Nestorian connection with the Indian church, however, this connection cannot be ignored. The most evident Nestorian writings found among the liturgies of the st. Thomas Christians are those of Diodorus, Adacus, Theodore, and Mare. Tisserant points out, however, that the inclusion of these writings in the liturgies of the St. Thomas Christians does not prove their adoption of Nestorian doctrine. ${ }^{1}$

In the seventh century a Nestorian was appointed as a leader for India; the exact location of his seat is not known. ${ }^{2}$ Mingana says that

in the seventh century there is a high authority of the Nestorian Patriarch Isho-Yab III (650-660), who had a regular hierarchy in India, under the jurisdiction of the East Syrian (Nestorian) patriarchate of Ctesiphon. ${ }^{3}$

Menon says, however, that Nestorianism was not introduced before the eighth century. ${ }^{4}$

${ }^{1}$ C. E. Tisserant, Eastern Christianity in India

(London: Longmans Green, 1957), 18.

${ }^{2}$ Firth, 27.

${ }^{3}$ Mingana $31-32$.

${ }^{4}$ K. P. Menon, $2: 148$. 
A second immigration took place in the ninth century. In 823 Syrian Fathers Mar Sapor and Mar Parut (Piruz) went to Kollam with Sabrisho. The king gave them privileges. ${ }^{1}$

Logan observes that the Nestorian arrival from Persia between the ninth and tenth centuries had no influence on the St. Thomas Christians, because they had an archdeacon and a well-developed liturgy from the earliest time. ${ }^{2}$ In fact, it was only to preserve the apostolic succession of its priesthood that the St. Thomas Church depended on the Persian church. An occasional arrival of a Nestorian bishop did not submit the church in India to the administrative control of the Patriarchs in Persia. ${ }^{3}$

Mathew explains the beginning of Christianity at Antioch, and later the relationship with Nestorianism. He concludes that the St. Thomas Christians were not Nestorians. He affirms that the concept of Nestorianism came to the church by Vettikkuttel Mathai, a priest who joined Mar Gabriel, the Metropolitan of the Nestorians who worked in Malankara from 1705 to 1731. It was his desire that the one whom he supported must be exalted by inserting

\footnotetext{
${ }^{1}$ Mingana, 45.

${ }^{2}$ Logan, 1:208.

${ }^{3} \mathrm{C}$. V. Cherian, 34 .
} 
Mar Gabriel's writing. ${ }^{1}$ Even when the Nestorians sent bishops they were not totally in control and only a few churches were under their rulership. ${ }^{2}$ Nestorians still remain as a separate group around Trichur, Kerala.

C. M. Agur says that Nestorius was considered as the father and supreme teacher of the faith of the Malabar Christians. ${ }^{3}$ It is also noted that Nestorius was a Syrian by birth. This may be a reason why the Christians of his own race and of the churches under their influence sided with him. ${ }^{4}$ Agur goes on to observe that Nestorianism and succession from St. Thomas went together and the Patriarchate of Babylon was throughout its vast extent Nestorian in doctrine and in the line of succession from Thomas. 5

By the end of the seventeenth century the Nestorians did not have sufficient members to constitute a metropolitan church; hence, in some places they united with their neighbors, and in other places, they were totally extinct. ${ }^{6}$

${ }^{1}$ P. M. Mathew, 97.

${ }^{2}$ Mar Aprem, The Chaldean Syrian Church of the East (Delhi: ISPCK, 1983), 25.

${ }^{3}$ C. M. Agur, Church History of Travancore (Madras: Asian Educational Service, 1990) 24.

${ }^{4}$ Ibid., 24

${ }^{5}$ Ibid., 27.

${ }^{6}$ James Hough, The History of Christianity in India (London: R. B. Selay and W. Burnside, 1839), 1:87-88. 


\section{St. Thomas Christians and the Roman Catholics}

The most famous among the early Portuguese who came to India was Vasco da Gama, who arrived in Cranganore on May 14, 1498. Later the Portuguese extended their territory to Cochin and Goa. Goa was made an archbishopric in 1557. The archbishop of Goa was the representative of the pope, with power over all of India, backed by the Portuguese armed forces. ${ }^{1}$

The Malabar church, which until then had been under the influence of the Nestorian Church of Persia, was forced to come under Roman jurisdiction. ${ }^{2}$ The authority of the church imposed on the Christians of St. Thomas was such that

the council of Goa resolved that the diocese of the Serra (Malankara) should be governed by a bishop appointed by the king of Portugal and not by the Chaldean Patriarch or if this transfer of authority was not expedient, that the Archbishop of Ankamali [the traditional title of the bishop of the St. Thomas Christians] should be bound to attend the council of Goa - . and any bishop coming to this Serra must first present his papers at Goa. ${ }^{3}$

The Roman Catholic Church, after establishing its hold on Kerala, started Latinizing the Syrian Christians. This enforcement was met with resistance for centuries.

\footnotetext{
${ }^{1}$ K. N. Daniel, 96.

Ibid., 96-97.

${ }^{3}$ L. W. Brown (1956), 23 .
} 
Inquisition

The Inquisition became a dark and blood-stained chapter in the annals of the history of St. Thomas

Christians in Kerala. Francis Xavier was the moving spirit behind the establishment of the inquisition in India. In a letter addressed to D. Joao III, king of Portugal on May 16, 1545, he wrote:

The second necessity for the Christians is that your majesty establish the Holy Inquisition, because there are many who live according to the Jewish law, and according to the Mahomedan sect, without any fear of God or shame of the world. And since there are many who are spread all over the fortresses, there is the need of the Holy Inquisition and of many preachers. Your Majesty should provide such necessary things for your loyal and faithful subjects in India. ${ }^{1}$

The inquisition was established at Goa with the help of Queen Catalina in March 1560 by Cardinal Henrique. ${ }^{2}$ In his History of the Inquisition in Goa, Dellon described the terrible condition of the prisoners. ${ }^{3}$

In a similar manner the Archbishop of Evora testified:

In the Goa tribunal, ironically called the Holy Office, the Inquisition would even arrest in their dungeons the women who resisted them and they would

${ }^{1} A$. K. Priolkar, The Goa Inquisition (Bombay: University Press, 1961), 24.

${ }^{2}$ Ibid. , 25.

${ }^{3} \mathrm{M}$. Dellon, The History of the Inquisition of Goa (London: Robert Owen, 1688), 32. 
satisfy their bestial instincts, after which they would be ordered burnt as heretics. ${ }^{1}$

Dellon describes the experience:

He [the Judaizer] again brought to audience some time after, and is asked diverse times in the same manner, without drawing any other answer from him. But at last the time of the auto da fe approaching, the promotor presents himself and declares to him, that he is accused by a good number of exceptional witnesses to have Judaized, which consisteth, in observing the ceremonies of the Mosaic Law, as not to eat swine's flesh, [or] hare, or fish without scales, to have assembled with others, and solemnized the sabbath day. ${ }^{2}$

One who denied the charges was condemned to be delivered to the secular arm to be punished according to the law, that is to be burned. ${ }^{3}$ During the Goa inquisition, hundreds of true Christians were burned for Judaizing, that is, keeping the Sabbath. ${ }^{4}$

Dellon's account, as cited by Priolkar, says

that of an hundred persons condemned to be burnt as Jews, there are scarcely four who profess that faith at their death, the rest exclaiming and protesting to their last gasp that they are Christians, and have been so during their whole lives; that they worship our Saviour as their true God; and that on his mercy, and the merits of his adorable sacrifice, alone, they

${ }^{1}$ Archbishop Evora, quoted in B. Radhakrishna Rao, "Christianity in India: A Critical Study on Inquisition in Goa," Vivekananda Kendra Patrika 8, no. 12 (1979): 171.

${ }^{2}$ Delion, 57

${ }^{3}$ Ibid.

${ }^{4}$ Priolkar, 34-35. 
repose their hope; but the cries and declaration of these unfortunates fail to touch these gentlemen. ${ }^{1}$

The St. Thomas Christians were accused in the remote parts of the diocese as guilty of working and merchandising on Sunday and holy days, especially in the evenings. ${ }^{2}$ The Inquisition not only punished the Jews and the Christians but also Muslims, Animists, and others who committed any of the prohibited offenses. ${ }^{3}$

For about two hundred years, atrocities and inhuman acts were inflicted upon the once independent and peaceful church. Howard observes:

This monstrous interference, on the part of the Jesuit, in the affairs of an independent church, was only the commencement of a series of similar acts, which became more and more violent, until at length they culminated in the atrocious horrors of the Inquisition about the year 1564 or 1565, and from that time down to the present the history of the church in Malabar presents a scene of continual turmoil, rivalry, and confusion, the pursual of which leaves a most painful impression on the mind. ${ }^{4}$

The peace and tranquility that existed among the Indian Christians were shattered. Thousands of innocent Christians were burned at the stake for their faith.

${ }^{1}$ Ibid., 35.

${ }^{2}$ Rae, 238 .

${ }^{3}$ Ibid., 200.

${ }^{4}$ George Broadly Howard, The Christians of St. Thomas and Their Liturgies (London: John Henry James Parker, 1864), 24 . 
Finally the famous liberal minister of Portugal, Marquez de Pombal, as a result of a measure of reform passed in

September 1774, judged that the inquisition was practically defunct. It was finally abolished in $1820 .^{1}$

The cruelty shown to the innocent was so great that the Portuguese feared that the Marathas would attack Goa; hence, the Inquisitors ordered that all the records should be placed in boxes and sent to the port of Mormungao. All except a few papers were burned in $1813 .^{2}$

\section{Synod of Diamper, 1599}

Dom Alexis de Menezes came to Cochin in February 1599. He felt that the Christians of Malankara had been wrongly instructed and that they must be brought back to the "true pastoral staff of Peter's successor." 3 To achieve this, Menezes started to visit the parishes. He promoted the Pope instead of the Patriarch of Babylon. He found it very hard to bring the syrian Christians into subjection. The Portuguese gave the king of Cochin 30,000 ducats; with his help they persecuted the Christians in Cochin. ${ }^{4}$

\footnotetext{
${ }^{1}$ Priolkar, 20-21.

${ }^{2}$ Ibid., 33-34

${ }^{3}$ Tisserant, 50 .

${ }^{4}$ Zacharia, 13 .
} 
At this time Archdeacon Geevarghese was the leader of the Malankara Christians. He advised the priests to receive Menezes with due respect but as a foreign prelate. Menezes won some Christians to his side and ordained thirty-eight priests. To this Archdeacon Geevarghese objected, but found himself helpless. Menezes forced the Archdeacon to acknowledge the authority of the Archbishop of Goa. He also summoned a synod at Diamper to be held June 20, 1599.' The synod was held in the Church of All Saints at Diamper, about fourteen miles east of Cochin. The crowds began to gather early. The government officers from Cochin included the Portuguese governor, who came "with a large staff of officers, richly costumed in silk, velvet, and lace, blending in dazzling colors with polished mail and plumed helmets."2 The papal church was represented by the dean, pastor, and choir. Along with them came the town council, accompanied by merchants and captains of ships. In fact, all within traveling distance left their ordinary affairs in order to be present on the opening day. ${ }^{3}$

The synod started its deliberations on June 20, 1599, and was attended by 153 clergy and 660 representatives of

${ }^{1}$ K. N. Daniel, 100-101.

${ }^{2} D^{\prime}$ orsey, $215-216$.

${ }^{3}$ B. G. Wilkinson, Truth Triumphant (Mountain View, Calif.: Pacific Press, 1944), 324. 
the laymen. The property of the churches not represented was confiscated by the decree of the king of Cochin. ${ }^{1}$

The synod continued until June 26, 1599. In nine sessions 267 decrees were voted. One of the decrees made Alexis de Menezes, the Goa Metran, the metran of Malankara. ${ }^{2}$

Finally the Archbishop called upon the synod members to sign the decrees. A priest standing in the midst of the assembly, with his trousers on his shoulders and shirt on his legs, expressed the opinion that matters were all turned upside down. He was immediately taken out of the church. On June 26, 1599, the Church of Malabar was placed under the protection of the king of Portugal, ${ }^{3}$ who in turn agreed to grant 15,000 cruzados annually for the maintenance of vicars and churches, exclusive of a large supply of wine for the celebration of masses under the Latin rule. ${ }^{4}$

In the Synod of Diamper, three decrees stand out. First, there was the decree demanding celibacy of the clergy. Fortunately it was not enforced, for it would have

${ }^{1}$ P. M. Mathew, 50.

${ }^{2}$ Ibid., 51

${ }^{3}$ E. M. Philip, The Indian Church of St. Thomas (Kottayam, Kerala: Bharat, 1907), 120.

${ }^{4}$ Ibid. , 120 . 
required all priests to put away their wives and children without support. 1

The second decree ordered that all books written in Syriac were to be handed over to the Metropolitan to be burned. St. Thomas Christians today believe that because of this, no records are available to recover and establish their past history. ${ }^{2}$

of major importance to this study are decrees 15 and 16 from the eighth session. These condemned those who observed the seventh-day Sabbath to be burned at the stake. ${ }^{3}$

By the actions of the synod, the freedom of the Malankara Church was crushed. Wilkinson points out that the St. Thomas Christians "could not tolerate the worship of images, the adoration of relics, processions, incense, the confessional, and all ceremonies" of the Roman Church. They longed for the biblical teaching of the word of God. They longed for the apostolic writings which they cherished as their heritage. They strongly resented their bondage and desired freedom from Roman Catholic bondage. ${ }^{4}$ In this

\footnotetext{
${ }^{1}$ Wilkinson, 325 .

${ }^{2}$ K. N. Daniel, 104, 105 .

${ }^{3}$ Zacharia, 189.

${ }^{4}$ Wilkinson, 329 .
} 
situation the Syrians sent complaints to Rome but received no response. ${ }^{1}$

Oath at the Humbled Cross

In 1653 an incident occurred which fanned growing discontent into flame. The Patriarch of Babylon made another attempt to get in touch with the Syrian Christians of Malabar by sending them a bishop named Ahattalla. The Portuguese found this out and seized the bishop on his arrival, put him on board a ship at Cochin, and deported him to Goa, where he was tried by the Inquisition and eventually burned at the stake. ${ }^{2}$

When the Syrians heard of this, they assembled in thousands around a large granite cross, the Kunan Kurish (Humbled Cross), on the grounds of the Mattanchery parish church, near Cochin, on January 16, 1653. There they took an oath to submit no longer to the ecclesiastical authority of Rome. They decided that they would only obey Archdeacon Thomas until they could get a bishop from the Eastern Church. ${ }^{3}$

The number of people who took part in the sathyam (oath) was so large that all could not touch the granite

${ }^{1}$ Keay, 53.

${ }^{2}$ Ibid. , 54.

${ }^{3}$ K. N. Daniel, 111. 
cross at the same time. Hence, they held on to ropes tied to the cross in all directions. The Syrian Christians who broke with Rome arranged a temporary government for the diocese and chose Archdeacon Thomas to be their next bishop. ${ }^{1}$ According to tradition, of 200,000 St. Thomas Christians, only 400 remained true to the Roman Archbishop Gracia.2

At this crucial point in history, fragmentation of the St. Thomas Christians began. Several rival groups were formed through the centuries and continue until the present.

${ }^{1}$ Ibid. , 113.

${ }^{2}$ Ibid., 111 
CHAPTER IV

EVIDENCES OF SABBATH KEEPING

This chapter contains evidences of Sabbath keeping among the St. Thomas Christians in Kerala. This information is divided into sections: the first six centuries and from the seventh to the sixteenth centuries.

In the first century the Sabbath appears to have been kept by all Christians. From the second century onward, Christians in the West began to abandon Sabbath observance, while those in the East kept on worshiping on the seventh day. ${ }^{1}$ Latourette notes that around the world, "up to the middle of the fifth century Christians were still observing the Jewish Sabbath."2

${ }^{1}$ D. E. Maxson, "Seventh-Day Baptists," ed. Philip Schaff, Religious Encyclopaedia or Dictionary, vol. 4 (New York: Funk \& Wagnalls, 1891), 2166. For information on this change, see Samuele Bacchiocchi, From Sabbath to Sunday: A Historical Investigation of the Rise of Sunday Observance in Early Christianity (Rome: Pontifical Gregorian University Press, 1977); Kenneth A. Strand, ed., The Sabbath in Scripture and History (Washington, D.C.: Review and Herald, 1982).

${ }^{2}$ Kenneth Scott A. Latourette, History of the Expansion of Christianity, vol. 1, The First Five Centuries (Grand Rapids: Zondervan, 1974), 305. 


\section{The First Six Centuries}

Christian writers generally agree that in the earliest period of the church, the Jewish Sabbath (Saturday) was

observed. "The early apostolic writings bear witness to the sanctity of the day dedicated to the duties laid down in the fourth commandment, the equivalent in the Christian religion of the Jewish Sabbath (Saturday)."1

\section{Jewish Christians}

The Jewish character of early Christianity is undeniable. According to Thomakathanar Koonammakal, "This Jewish-Christian element was reflected in the religious, socio-cultural, and linguistic heritage of early Christianity in India." He goes on to say that Christianity emerged as a semitic religion. ${ }^{2}$

If the Christian church in Kerala arose among converted Jews, worship on the seventh day would have been expected. ${ }^{3}$ Thomas affirms that they continued the Jewish system of worship and also kept the law. ${ }^{4}$ Mathew observes:

${ }^{1 E n c y c l o p e d i a ~ B r i t a n n i c a, ~} 1946$ ed., s.v. "Sunday."

${ }^{2}$ Thomakathanar Koonammakal, "Semitic Dimension of Christian Tradition," The Harp 10 (1997): 71.

${ }^{3}$ See Cherian, 33-36.

${ }^{4} \mathrm{M}$. K. Thomas, Kananyakuraum Puthiya Nivamavum [Cananites and New Testament] (Trivandrum: Arimathia, n.d.), 35 . 
"From the first century up to the advent of the Portuguese in 1499 A.D., the St. Thomas Christian Church was loyal to the Christian church in Jerusalem and were observing its faith and practices."1

\section{Non-Jewish Christians}

Mingana points out that "as early as A.D. 225 there existed large bishoprics or conferences of the church of the East stretching from Palestine to India."2

Brown says that "St. Thomas founded churches among the Jewish colony around the Periyar River." 3 And Francis Buchanan says that "Nazarenes or Malabar Christians had high Jewish features, in their church they had neither images nor pictures."4 Furthermore, Stewart adds that they were particular and devout in their Sabbath attendance. ${ }^{5}$

Babu Paul, the undersecretary. of the Government of Kerala and an orthodox Syrian Christian, wrote a Bible Dictionary in Malayalam. He says: "It was in the fourth century A.D. that sunday was particularly separated as a

${ }^{1}$ P. V. Mathew, 75.

2Mingana, 5 .

${ }^{3}$ L. W. Brown, 62 .

${ }^{4}$ Francis Buchanan, Journey from Madras through the Countries of Mysore, Canara, and Malabar (Madras: Asian Educational Service, 1988), 2:391.

${ }^{5}$ Stewart, 125 . 
church day and Sabbath changed." ${ }^{1}$ This would suggest that until the fourth century the Sabbath was kept among the St. Thomas Christians in Kerala.

Given the contacts between the Syrian Church, Nestorianism, and Indian Christianity, one might expect to find commonalities among the three. Thus, Sabbath observance, from sundown to sundown, ${ }^{2}$ could have occurred in India as well as in the other communities. ${ }^{3}$

Moraes points out that "the practice lof Sunday worship) started at the time when the Persian church established control over the Indian church." 4 He relates this to the coming of Thomas of Cana.

While the statement does suggest that until the fifth century the Thomas Christians were Sabbath keepers, Moraes is in error on the date of Thomas of Cana, which, according to the Canaanite Christian record, happened in A.D. 345.

${ }^{1}$ D. Babu Paul, Vedha Ratna Karam [Bible Dictionary] (Trivandrum: State Institute of Language, 1997), 279 (Translation mine).

${ }^{2}$ W. J. Richards, The Indian Church of St. Thomas (London: Bemrose and Son, 1908), 100.

${ }^{3}$ V. K. George, 41-42; Adrian Fortescue, The Lesser Eastern Churches (London: Catholic Truth Society, 1913), 301-319; Harry Middleton Hyatt, The Church of Abyssinia (London: Luzac, 1928), 224 .

${ }^{4}$ Moraes, $1: 64$. 
Podipara notes that "the immigrants did not make any change among the St. Thomas Christians," ${ }^{1}$ because "even the Persian Church was founded by Apostle Thomas." 2 P. V. Mathew agrees, affirming that the st. Thomas Christians in Kerala and the immigrants accepted the same faith and followed the same liturgy ${ }^{3}$ and "they practiced Sabbath as Nazranis or Essenes." 4

Mar Aprem, a Canaanite Orthodox Christian Metropolitan in Kerala, the author of a dictionary of church history, affirms that Sunday was not declared a day of rest by civil and religious laws until the fourth century, ${ }^{5}$ which would indicate exclusive seventh-day Sabbath observance until that time.

Thus, it seems beyond doubt that sunday was not observed among the Malabar Christians during the first four centuries.

${ }^{1}$ Podipara, The Malabar Christians, 64, 104.

${ }^{2}$ K. N. Daniel, 55-56.

${ }^{3}$ P. V. Mathew, 214 .

${ }^{4}$ Danielou, 34, 123 .

${ }^{5}$ Mar Aprem and T. P. Abraham, Dictionary of Church History (Kottayam, Kerala: Ashram, 1986), 33. 


\section{Seventh to Sixteenth Centuries}

Mar Aprem points out that Sunday was not introduced in Kerala until the fourth century and gradually made compulsory between the sixth and the thirteenth century. ${ }^{1}$

P. Thomas, on behalf of the Ministry of Information and Broadcasting of India, writes on the church life of Syrian Christians before the Portuguese period:

Apart from the need for public worship on the Sabbath, the church is a place of daily worship too for many Christians. The pious attend the church as often as they can, for prayer and meditation. ${ }^{2}$

The Nestorian Connection

During the medieval period, the Nestorians in Kurdistan besides having numerous fasts, forbidding meat on 152 days, and shunning pork, kept both Sabbath and Sunday. ${ }^{3}$

In the "early sixteenth century, the Abyssinian, Armenian, and Nestorian Churches, the first day of the week had not yet replaced the observance of the seventh day." 4

${ }^{1}$ Ibid. , 133

${ }^{2} \mathrm{P}$. Thomas, 8 .

${ }^{3}$ K. Kessler, "Nestorians," The Schaff Herzog New Encyclopedia of Religious Knowledge (London: Funk and Wagnalls, 1910), 8:120-123.

${ }^{4}$ Maxson, 2166. 
Fortescue states that the Jacobites kept the Sabbath as did the Coptic, Abyssinians, and Ethiopians. ${ }^{1}$ The relations between the Malabar church and the Jacobites could suggest that they too kept the Sabbath.

Mar Jacob, a Nestorian or Armenian bishop of the St. Thomas Christians, writing around 1500, reported that at the seminary in Cranganore, "On Saturdays regularly four of the students and sometimes six and even eight, go out together with some ordained priests, to say masses in the places and churches of the Christians and to preach and teach religion."2 This could suggest that the Saturday Sabbath was still observed at the time the Portuguese came to India.

\section{The Goa Inquisition}

An important objective for the establishment of the Inquisition at Goa was to eradicate Sabbath observance. Lobley says that, as in Europe, the inquisition's "power was first exercised upon those who were suspected of Judaism." 3 St. Thomas Christians, who followed the law of Moses, were called Judaizers. ${ }^{4}$ The Catholics accused the Syrians by

${ }^{1}$ Fortescue, 279-352.

${ }^{2}$ Mundadan, 1967:121.

${ }^{3} \mathrm{~J}$. A. Lobley, The Church and Churches in South India (London: Deighton, Bell and Co., 1870), 32 .

${ }^{4}$ Fortescue, 363. 
saying, "There were many Christians, who practiced Jewish rites." 1

Dellon mentioned the case of a wealthy man who had been accused of Judaizing. After his death, his remains were exhumed and burned in the early part of the seventeenth century. ${ }^{2}$

During the Latinization period, at the close of the sixteenth century, there were heated arguments on Sabbath and Sunday observance between Archbishop Gouvea and the Archdeacon of the St. Thomas Christians. The Archbishop claimed that none could be saved who were not obedient to the church of Rome. He argued that they had in their archives a letter of St. Caius, bishop of Rome, wherein the bishop disavowed all relationship with the church of Babylon, that is the Nestorian church. The Archdeacon counter argued by saying: "We possess also another letter which is called in our record, the letter on the Lord's day, and is said to have been dictated by our Lord, having been written by an angel, and is said to have fallen from heaven on a Sabbath day while the people were assembled in the church." ${ }^{3}$

${ }^{1} D$. Sam, History of the Catholic Church in India (Bombay: B. X. Furtado \& Sons, 1910), 106.

${ }^{2}$ Dellon, 104 .

${ }^{3}$ Hough, $1: 369$. 
H. H. Mayers quotes Nicolo Conti as affirming that the "Syrian, Jacobite, and Armenian Christian churches were scattered all over India in like manner as are the Jews among us." ${ }^{1}$ Christians living in places remote from centers of commerce observed the Sabbath on Saturdays and worked on Sundays. ${ }^{2}$

According to Adeney the introduction of the Inquisition into India was "not invoked to plough up fallow ground; it was demanded in order to remove rocks of offence." ${ }^{3}$ Then he quotes from the letter written by Francis Xavier in 1545 to the king of Portugal to establish the Inquisition in order to check "the Jewish wickedness" that was spreading through the king's Eastern dominions. ${ }^{4}$

Rae points out the task of the Inquisition: "Hunting down heretics, Jews, New Christians and all who were accused of Judaizing (that is conforming to the ceremonies of the Mosaic law, such as not eating pork, attending the

${ }^{1} \mathrm{H}$. H. Mayers, The Inquisitive Christians (Morisset, N.S.W.: New Millennium, 1992), 41.

${ }^{2}$ Ibid.

${ }^{3}$ Walter F. Adeney, The Greek and Eastern Churches (Edinburgh: T. \& T. Clark, 1908), 527.

${ }^{4}$ Ibid., 528 
solemnization of the Sabbath, partaking of the Paschal lamb, and so forth)."

The noted geographer of the seventeenth century, Samuel Purchas, who speaks of the Jacobite branch of the Eastern church in India, wrote: "They keep Saturday holy, nor esteem Saturday fast lawful but on Easter Even. They have solemn service on Saturdays, eat flesh, and feast it bravely like the Jews." 2

The Synod of Diamper

After the Synod of Diamper (1599), the St. Thomas Christians faced a stern warning related to their lack of respect for Sunday observance.

The synod being informed that in the remote parts of this bishopric, as well towards the South, as towards the North, the Christians that dwell in the heaths are guilty of working and merchandizing on sundays, and holy days, especially in the evenings, doth command the vicars to be very vigilant in this matter and to admonish and reprehend all that they shall find so doing, and if after three particular admonition, they be thrown out of the church, and have the casture denied them, neither shall any priest go into their houses until they have yielded obedience. ${ }^{3}$

${ }^{1}$ Rae, 200.

${ }^{2}$ Samuel Purchas, His Pilgrims (New York: AMS Press, $1965), 8: 73$.

${ }^{3}$ Michael Geddes, The History of the Church of Malabar from the Time of Its Beginning Until Eirst Discovered by the Portuguese in the Year 1501 (London: S. Smith and B. Walford, 1694), 367. 
Purchas also said that the syrian churches "celebrate Divine Service as solemnly on the Sabbath, as on the Lord's Day; that they keep that day festival, eating therein flesh, and fast no Saturday in the year but Easter eve, . . that they acknowledge not purgatory." I

The cruel punishment that was inflicted on the Sabbath keepers can be further seen from the "edict of faith" that was used against the St. Thomas Christians after the Synod of Diamper in 1599.2 The edict condemned "any person who after receiving baptism has had belief in the Mosaic law, subsequent to the last general pardon which was published on the 5th of January 1605." In addition, "Performing Jewish rites and ceremonies, namely not working on Saturday but remaining dressed on that day as on a feast day, commencing the observance on Friday evening, always abstaining from the flesh of pig, hare and rabbit, and scaleless fish and other things prohibited in the old law were also condemned as heretical." 3

Claudius Buchanan, who carried out Christian research early in the nineteenth century, reveals some surprising

\footnotetext{
${ }^{1}$ Purchas, 1:351-353, quoted in Wilkinson, 327.

${ }^{2}$ Priolkar, 92 .

3'Ibid., 92-95.
} 
information regarding another branch of the Eastern church, the Armenians of India:

They have preserved the Bible in its purity and their doctrines are, as far as the author knows, the doctrine of the Bible. Besides, they maintain the solemn observance of Christian worship, throughout our Empire, on the seventh day; and they have as many spires pointing to heaven among the Hindoos, as we ourselves. Are such a people then entitled to no acknowledgment on our part, as fellow Christians? Are they forever to be ranked by us with Jews, Mahomedans and Hindoos? ${ }^{1}$

Recalling what was imposed on the St. Thomas Christians during the Synod of Diamper, Krishnankutty notes the "imported goods of the Roman Catholic Church": "Pope, Priests, Bishops, Cardinals, Nuns, worship of Saints, bowing down to cross, purgatory, mass, virgin Mary, and the observance of Sunday."2

\section{Recent References}

Moothampackal Kochukunju Upadesi, an early nineteenthcentury Marthomite preacher, inscribed in Malayalam on a stone pillar, the phrase, "Observe the Sabbath." ${ }^{3}$ He composed four songs on the Sabbath; all four are in the

\section{${ }^{1}$ Claudius Buchanan, Christian Research in Asia} (London: G. Sydney, 1812), 266.

${ }^{2}$ Thiruvattar Krishankutty, Yesu Kristhu Sampoorna Viplavarkari [Jesus Christ the Complete Revolutionist] (Eraviperoor, Kerala: Noble, 1988), 77.

${ }^{3}$ Moothampackal Kochukunju Upadesi, stone inscription in Malayalam, Edyarumula, Kozhanchery, Kerala, seen and photographed by the researcher (April 13, 2000). 
Seventh-day Adventist song book (Truth in Song) in Kerala.

In two of the songs the following words are recorded:

The Seventh-day is the Sabbath of the Lord. Do not change it in vain into the first day . . Seventh-day is the Saturday of the week. All must know, not the Sunday of the week . .

Another song says:

The holy day is for the service to the king supreme and not for us.

This is the day for us to come together and worship Him.

Whosoever spends the holy day in vain surely, God will punish him though He is merciful.

Many people stay at home, many go for shopping Many do work; very few in the house of God. God Himself caused ways for the Sabbath breakers to lead the life of bondage for seventy years. oh, Sabbath breaker, come back and worship Lest you should be affected by the fiery flames of His dreadful wrath. ${ }^{1}$

Ashok Sardar, Dean of Religious Studies, Bangalore College, published a two-page English and Tamil pamphlet on the Sabbath. He concluded by saying:

Since the New Testament had still not been written down, Christians of the first century used exclusively the old Testament to evangelize the world. It might surprise some to learn that the Christian message reached India before it reached most of Europe. They found the old Testament quite consistent with their beliefs and unlike today's Christianity, they did not regard it as a book stripped of all authority. . . . Jesus neither by example or precept declared that the

${ }^{1}$ Songs No. 298, 299, Sathya Pradeepa Ganangal [Truth in Songl, 5 th ed. (Thiruvananthapuram, Kerala: South Kerala Section of SDA, n.d.). 
sanctity of Saturday as a day of rest had been transferred to any other day. ${ }^{1}$

$$
\text { Ayyar describes the history of Malabar Christians: }
$$

The first converts were Jews who were accustomed to worship in the synagogues and they, no doubt, continued it. As the years went by, they made such changes as their new ideas suggested. They continued to observe the Mosaic laws which include the worship on the seventh-day Sabbath. Their rites and customs were sanctioned by tradition. ${ }^{2}$

Thus the ancient Syrian Church, the St. Thomas Christians, provides undeniable evidence of the observance of the biblical seventh-day Sabbath.

${ }^{1}$ Ashok Sardar, "Sunday Not Holy Day," The Chilliwack Progress, July 30, 1986.

${ }^{2} \mathrm{~L}$. K. Anantakrishna Rao Bahadur Ayyar, Anthropology of the Syrian Christian (Ernakulam, Kerala: Government Press, 1926), 157. 


\section{CHAPTER V}

\section{THE FRACTURING OF THE ST. THOMAS CHRISTIANS}

The St. Thomas Christians of India remained united for centuries, holding as an article of faith the belief that their community had been founded by the apostle Thomas. ${ }^{1}$ This chapter will discuss their fragmentation, beginning in the seventeenth century.

Today there are nine groups that merit description. These are considered in the rest of the chapter. A graphic illustration of the division of the st. Thomas Christians appears in the appendix.

\section{Syro-Malabar Church}

After the incident of the Kunan Cross Oath (1653), the Syrian church divided, and this division has never been healed. The pope sent Carmelite fathers and a bishop named Joseph to try to reconcile the Archdeacon (Mar Thoma) and his followers to the Jesuit Archbishop Gracia. ${ }^{2}$ The

\footnotetext{
${ }^{1}$ L. W. Brown, The Indian Christians of St. Thomas
} (Madras: B. I. Publications, 1980), 43.

$$
{ }^{2} \text { Keay, } 56 \text {. }
$$


Archdeacon did not yield, but some of his followers were ready to compromise. Parambil Chandy, a near kinsman of the Archdeacon, was one of these. Some eighty-nine

congregations returned to the Roman Catholic Church and only thirty-two remained faithful to the Archdeacon and the Kunan Cross Oath. ${ }^{1}$

Syrian Christians who were loyal to Rome came to be known as Romo-Syrians or the Syro-Malabar Church. They are also known as Pazhayakuttukar (old party), in contradiction to the Puthankuttukar (new party), who did not join them but opted to stay with Mar Thoma. ${ }^{2}$ The Roman Catholics in Malabar today claim this as proof that the Romo-syrians (Syro-Malabar Church) represent the original church and that the new party is the offshoot.

By the beginning of the seventeenth century, the Roman church "wanted to destroy the Portuguese rule (Padroado fide) of the mission in the East," 3 and "organized the 'Propaganda fide' for mission in the East." 4 In 1663 the

${ }^{1}$ Ibid.

${ }^{2}$ Benedict Vadakkekara, origin of India's St. Thomas Christians (Delhi: Media House, 1995), 88-91.

${ }^{3}$ M. O. John, The Thomas Christians in India (Ernakulam: Korah Varghese, 1987), 54.

${ }^{4}$ Ibid., 54 
Dutch captured Cochin and all the foreign clergy, including Bishop Joseph Sebastiani, the papal nominee, had to leave. ${ }^{1}$

In time the relationship between Rome and the Dutch improved. Seizing this opportunity, Rome sent some Carmelites to Malabar. But the Portuguese were not ready to accept the authority of the Propaganda fide and the Carmelites in Malabar. Thus there was struggle between these two groups (Padroado and Propaganda fide), ${ }^{2}$ who appointed their own bishops in Malabar and did not allow any Indian leadership.

Syrian Christians under this Latin rulership were unhappy and sent complaints to Portugal and Rome to seek redress of their grievances. Rome did not hear the complaints of the Indians. ${ }^{3}$ But Queen Maria of Portugal did help by appointing a native archbishop. Later, "the syroMalabar hierarchy was separated from the Latin and established in 1887 by Pope Leo XIII for the Christians of St. Thomas." 4

According to the Catholic Directory of Kerala, in 1986 the Syro-Malabar Church had a total membership of $2,697,677$,

${ }^{1}$ Ibid. , 54-55.

${ }^{2}$ Ibid., 55-56.

${ }^{3}$ Ibid., 56

${ }^{4} \mathrm{Joseph}, 259,260$. 
with two archdioceses, and 9 dioceses. There were 24 minor seminaries and 3 major seminaries, 36 colleges, 389 high schools, 370 middle schools, 660 primary schools, 798 nursery schools, and 280 industrial, technical, and vocational training centers. In addition, the church had 1,273 charitable institutions, 178 hospitals, 135 dispensaries, 141 orphanages, and 63 special care centers. There were 24,154 priests and 24,571 nuns. The Syro-Malabar church follows the Chaldean liturgy. ${ }^{1}$

\section{The Syro-Malankara Church}

In 1882, Father P. T. Geevarghese, a highly educated priest of the Syrian Orthodox Church, stood firm with Vattaserril Mar Dionysius in his struggles to defend the autonomy of the church. With the help of Mar Dionysius as leader and generous contributions from church members, he founded a monastery called Bethany Ashram at Perunadu near Ranni and also many churches. ${ }^{2}$

In 1925 Father P. T. Geevarghese was consecrated bishop in the Orthodox Church at Niranam and assumed the title Mar Ivanios. Later he was installed as the Metropolitan of Bethany. During this time the dispute

${ }^{1}$ Catholic Directory of Kerala (Angamaly, Kerala: P. V. Varkey and Baby Jose, 1986), 506-507.

'John, 45. 
within the church between the Patriarchs' Party (Bava Kakshi) and the Catholicos' Party (Metran Kakshi) became worse. Mar Ivanios observed the organization, unity, and strength in the Roman Catholic Church, and proposed a union with Rome. ${ }^{2}$ But Mar Dionysius and the Syrian Orthodox Church rejected it. Mar Ivanios contacted Rome and joined the Catholic Church in 1930, along with his assistant bishop, a few priests and followers; they formed the syroMalankara Church. ${ }^{3}$

This group claimed to be the church founded by the apostle Thomas. Its hierarchical structure consists of a metropolitan and two suffragans. The church follows the Antiochean rite. ${ }^{4}$

According to the Malankara Catholic Directory, in 1999 the Syro-Malankara Church had 225,000 members, and 556 parishes and mission stations. They operated 6 seminaries (5 minor and 1 major), 4 colleges and training schools, 2 higher secondary schools, 4 technical institutes, 21 high schools, 26 middle schools, 98 primary schools, 60 nursery schools, and 25 industrial and vocational training centers.

\footnotetext{
${ }^{1}$ Ibid. , 46.

I'Ibid., 46.

${ }^{3}$ Ibid. , 46.

${ }^{4}$ Keay, 94.
} 
The Syro-Malankara Church has 12 hospitals, 6 dispensaries, 8 orphanages, 11 special care centers, 4 homes for the aged. There are 15 pious associations, 756 religious sisters, 413 priests (Eparchial, Religious), 3 rehabilitation centers, 1 Dalit hostel, 3 publications, and 34 ashrams. $^{1}$

\section{Syrian Orthodox Church}

The main body of the Syrian Church in Malabar, which continued under the Patriarch of Antioch after the Mar Thoma Church separated in 1889, is generally known as the Orthodox Syrian Church or the Jacobite Church. ${ }^{2}$ It is also sometimes called the Orthodox Syrian Church of the East by those who are followers of the Catholikos. Presently the Orthodox Syrian Church is divided into two parties known as the Patriarch's Party and the Metran's Party. ${ }^{3}$

The Patriarch's Party seems to predominate in the northern parts of Travancore and the Metran's Party in the southern part of Travancore. A majority of those who have received a higher English education side with the Metran. In some places where the parties are evenly matched there

${ }^{1}$ Malankara Catholic Directory (Trivandrum, Kerala: St. Mary's Offset, 1999), 78-80.

${ }^{2}$ Keay, 92.

${ }^{3}$ Ibid. , 92 
have been disturbances, and churches had to be closed for years with no worship services. ${ }^{1}$

At present the Syrian Orthodox Church has a membership of over 2,100,000, with 21 dioceses all over the world. They have 1,295 parishes, 175 chapels and worship centers, 2 theological seminaries, 18 monasteries and convents, 18 colleges, 230 schools, 28 hospitals, 26 homes for orphans and the destitute, 18 training schools, and 1 mission training center. ${ }^{2}$

\section{Independent Syrian Church or Thozhiyur Church}

This group of St. Thomas Christians began its autonomous existence in 1772 under the leadership of Mar Cyri1. ${ }^{3}$ Mar Gregorios was not satisfied with the way he was cared for by Mar Dionysius, so there was resentment between them. Mar Gregorios died in 1773, leaving all his property to Mar Cyril. The consecration of Mar Cyril was done in secret, without the presence or consent of any other bishop; this was not legal. Yet Vadakkekara notes that "on a strict interpretation of canon law it had to be accepted as

${ }^{1}$ Ibid., 93.

2The Orthodox Syrian Church Diary (Kottayam, Kerala: MGOCSM, 1997), 3 .

${ }^{3}$ Geevarghese Chediath, "A Voice in the Wilderness," Christian Orient Ecclesiology Book Review News 19 (March 1998): 13 . 
valid." Mar Cyril claimed power over the church in the Cochin area, and this authority was recognized by the Raja of Cochin.

In 1774, on representation from Mar Dionysius and Mar Joha as to the illegality of the consecration, the Raja withdrew his recognition and delivered Mar Cyril over to the custody of Mar Dionysius. ${ }^{2}$ The prisoner escaped and left the area controlled by the Raja of Cochin. He established himself at the small village of Thozhiyur, which was at that time in the dominion of the Zamorin, later British Malabar. His followers were very few, but he was supported by a number of priests and regarded himself as the head of the church.

In 1794, he consecrated as bishop his brother, who became Mar Cyril II in 1802. Since then the episcopal succession has been maintained without a break. Mar Cyril and his adherents took up residence at Anjuror Thozhiyur and called themselves the Independent Syrian Church of Malankara. ${ }^{3}$

\footnotetext{
${ }^{1}$ Vadakkekara, 106.

'Ibid., 106.

${ }^{3}$ Ibid., 107.
} 
The liturgical worship of the independent Syrian Church of Malankara follows the Antiochene tradition. ${ }^{1}$ The head of the church, Poulose Mar Philoxenos III, along with some of the clergy and the laity, became united with the Catholic Church on 28 August 1977. Mar Philoxenos became a member of the Syro-Malankara hierarchy. Matthew Mar Cyril succeeded Mar Philoxenos as head of the Independent Syrian Church of Malankara. ${ }^{2}$ This stagnant church continues its independent existence with 5,000 members and one bishop. ${ }^{3}$

\section{The Malankara Jacobite Syrian Orthodox Church}

This church separated from the Syrian Orthodox church in 1912. From 1913 onwards there were continuous civil litigations: Vatippanakkess, the dispute over the interest of the church money; Samudayakkess (1938-58), lawsuit on church matters; and Randam Samudayakess, which started in 1974 and continues today. ${ }^{4}$ There is no sign of peaceful settlement or coexistence between the two factions of this ancient community. Large numbers are moving from this church to various Pentecostal groups.

\footnotetext{
${ }^{1}$ Ibid., 107.

${ }^{2}$ Ibid. , 107.

${ }^{3}$ Chediath, 15 .

${ }^{4}$ Ibid., 16.
} 
At present this church is considered to be one of the Oriental Orthodox churches. It consists of two groups: Malankara Orthodox (Catholicos party) and the Syrian Orthodox (Patriarch Party).

The Malankara Jacobite Syrian Orthodox Church follows the west Syrian liturgy. They are in ecumenical relationships with the Roman Catholic Church and against the Protestants.

They claim over 1,500 parishes with fifteen dioceses and nearly one million adherents. They own 5 colleges, 200 schools, 4 hospitals, 1 seminary, 5 training schools, and have 30 churches outside of Kerala. ${ }^{1}$

\section{The Church of the East or the Surrays}

The Church of the East, which has its headquarters at Trichur, Kerala, can be considered as a remnant of the Thomas Christians. ${ }^{2}$ They broke away from the Syro-Malabar Church in 1908. The followers of this church are concentrated in Trichur and are known as "Surrays" or "Chaldeans." 3 Presently, they are divided under two bishops and together have seventeen parishes and fifteen thousand

${ }^{1}$ K. P. Cherian, Priest, St. Mary's Church, Pune, interview by author, August 18, 1998.

${ }^{2}$ John, 59.

${ }^{3}$ Ibid. , 60 . 
followers. They are in relationship with Mar Dinkha IV of the Assyrian Church, but they are not Assyrians. ${ }^{1}$

\section{Mar Thomite Church}

In the mid-nineteenth century, the Orthodox syrian or Malankara Church entered into a period of upheaval. Cheppad Mar Dionysius was confronted with an internal problem which threatened the faith of the church as well as its authority. The Protestant missionaries had sown seeds of reformation in the church. Father Abraham Palankunnath of Maramon was the leader of this reform movement. He was a Malpan (priest) and Syriac professor in the theological seminary at Kottayam. He demanded changes in the prayers to the departed, intercession of the blessed virgin Mary and the saints, and the celebration of the festivals. ${ }^{2}$ He made alterations in the ancient liturgy of St. James and removed the sacrificial aspect of Holy Qurbana (Lord's Supper). In these circumstances, Mar Dionysius issued a circular to all parishes instructing them not to be misled by Malpan's teachings and to stand firm in the orthodox faith. The reformers counteracted by submitting a memorandum against

\footnotetext{
${ }^{1}$ Chediath, 17 .

${ }^{2}$ Joseph, 358 .
} 
Mar Dionysius to the British President in 1836, asking him to dismiss Mar Dionysius. This was not done. ${ }^{1}$

Abraham Malpan took leave from the seminary and went home to Maramon, where he celebrated the Qurbana using his reformed liturgy and thus started the reformation in 1837 . Mar Dionysius excommunicated the Malpan for his unethical and disloyal acts and disobedience to the head of the church. Malpan realized his need for the support of the metropolitan to make further progress in his reformation. Hence, he sent his nephew, Deacon Matthew of Palakunnath, to the Patriarch of Syria for consecration as Metropolitan. Under the name Mar Athanasius, Deacon Matthew became the first national to receive full consecration as a Metropoliton direct from the Patriarch of the Syrian Church. In 1843 Mar Athanasius returned to Malankara, superseded Mar Dionysius, and prevailed over his opponents until his death in $1877 .^{2}$

The majority of those who had been influenced by the evangelical teaching continued in the syrian church and argued their point of view. Ultimately "the Patriarch himself, the successor of the one who consecrated Matthew Mar Athanasius had to come to Kerala. He presided over the

\footnotetext{
${ }^{1}$ Keay, $80-81$.

${ }^{2}$ K. N. Daniel, 163 .
} 
Synod at Mulathuruthy in the year 1876-1877."1 A litigation for the possession of the properties of the church began in 1879. Ten years later the case was settled in favor of the patriarch's party. At last in 1889, two distinct churches came into being, known as the Mar Thoma Church and the Jacobite Church. ${ }^{2}$ The Mar Thoma Church still follows the rule of the Eastern Church, that bishops must be unmarried, but other clergy can marry. ${ }^{3}$ The church accepts the doctrine and belief of the Anglican Church, but retains the West Syriac liturgical practices and usages. It is in communion with the Church of South India (CSI), the Church of North India (CNI), and the Anglican Church. ${ }^{4}$ The Mar Thomite Church has over 875,000 adherents. At present they have many members in dispersion, with 22 parishes in Malaysia, 97 in the Persian Gulf, 9 in Canada, and 80 in other parts of India, making a total of $965 .{ }^{5}$ There are about 12,000 members from the lower classes in the Mar Thoma

${ }^{1}$ Ibid., 172.

'Joseph, 269-270.

${ }^{3}$ Keay, 94 .

${ }^{4}$ Vadakkekara, 108 .

${ }^{5}$ L. W. Brown (1980), 299. 
Church, mostly organized in separate parishes, with three priests from that group. ${ }^{1}$

This church also has 117 lower primary schools, 15 upper primary schools, 15 high schools, 6 colleges, 1 training school, 6 theological institutions, 9 hospitals, 8 destitute homes, 12 social welfare institutions, 3 study centers, 12 children's homes, 4 hostels, 4 ashrams, and 8 publications. ${ }^{2}$

The Mar Thomite Church claims that it is the true representative of the ancient apostolic church founded in India by Thomas. "The reformation has cast out some of the erroneous beliefs and practices, most of which had crept in at the time of the Portuguese domination. Keay points out that neither Babylon nor Antioch ever had any established supremacy over it, although there had admittedly existed some sort of loose relationship between them and the Malabar see. ${ }^{3}$

\section{Central Kerala Diocese of the Church of South India (CSI)}

About 64 percent of the Central Kerala Diocese of the CSI membership are from the St. Thomas Christian tradition.

${ }^{1}$ Ibid.

${ }^{2}$ Mar Thoma Sabha Diary (Thiruvalla, Kerala: Mar Thoma Syrian Church, 1995), 3-14.

${ }^{3}$ Keay, 86. 
In 1836, when the Syrian Orthodox Church broke all relationships with the Western Protestant missionaries, about 6,000 Syrians joined the Anglicans (Church Missionary Society or CMS). ${ }^{1}$ The CMS diocese became part of the CSI in 1947. This group has about 55,000 members. They run schools and hospitals in Kerala.

\section{St. Thomas Evangelical Church of India}

The St. Thomas Evangelical Church of India broke away from the Mar Thomite Church in $1961 .{ }^{2}$ The history of the group is traced to the reform movement initiated by Abraham Malpan, one of the mentors of the Mar Thomite Church. The St. Thomas Evangelical Church considers itself the embodiment of the reform movement started by Abraham Malpan. On January 26, 1961, a group of eighteen priests, in order to engage actively in evangelizing, laid hands on two of their members and proclaimed them metropolitans. ${ }^{3}$ The group adopted the name, "St. Thomas Evangelical Church of India."4 This church is affiliated with the International Council of

\footnotetext{
${ }^{1}$ Chediath, 16 .

${ }^{2}$ Ibid., 17

${ }^{3}$ Vadakkekara, 111 .

${ }^{4}$ Ibid. , 111
} 
Christian Churches and "is split into two groups with a total of 5,000 members." 1

\section{Conclusion}

The ecclesiastical disintegration of the Syrian

Christians of Kerala is hard to understand. There is little intermarriage between Romo-Syrians and other Syrians, and little political and social cooperation. However, although the extent of separation has been fully recognized, culturally and socially the syrian Christians are seen as a community and are proud of their ancestry and identity. ${ }^{2}$

St. Thomas Christians have maintained some degree of unity, as Vadakkekara points out:

Years later in 1952 these groups came together once again to hold the nineteen hundredth anniversary of the landing on Malabar soil of their common Apostle. And in a like manner in 1972 they reassembled for celebrating the nineteen hundredth anniversary of the martyrdom of St. Thomas. ${ }^{3}$

Those reunions show how the community of India's St. Thomas Christians, despite not having much communication among themselves, still proclaim their common religious heritage. Yet, each group insistently claims to be a direct

\footnotetext{
${ }^{1}$ Chediath, 17 .

${ }^{2}$ L. W. Brown (1980), 300.

${ }^{3}$ Vadakkekara, 78 .
} 
continuation of the original church established by the apostle.

The Christian churches established in Asia after the beginning of the nineteenth century had a foreign origin. They are often branded as foreign. The syrian community has escaped this accusation, even though it also had a foreign origin and until 1665 used East Syriac in its liturgy. ${ }^{1}$ Independent India has accepted the ancient church as truly Indian, as presidents and prime ministers of India have made clear. Members of the Syrian community have held key positions as chief ministers and other important posts in the government. ${ }^{2}$ Though the church has gone through ecclesiastical disintegration, all branches claim apostolic faith.

${ }^{1}$ Koonammakal, 75 .

${ }^{2}$ Ibid., 300-301. 
CHAPTER VI

\section{STRATEGY FOR REACHING THE ST. THOMAS CHRISTIANS IN PALLIPAD}

From Viggo Soggard we learn that the term strategy "was originally used as a military term and as such reminds some people of strategies of war. But for most, the term is merely a convenient word for describing any kind of plan." Soggard further notes that "the development of a comprehensive, integrated strategy is like planning a 'highway' from the present position of our audience and on to a spiritual maturity." 2

Various stages are involved in the strategy to reach the St. Thomas Christians. These are the preevangelism period, the evangelistic crusade, and a postbaptismal care plan. The strategy must be planned on the basis of the configuration of this people group.

${ }^{1}$ Viggo Soggard, Media in Church and Mission (Pasadena: William Carey, 1993), 54.

${ }^{2}$ Ibid., 66 . 
The Target Group

A description of the target group involves the justification for a people group approach, the location and the number of people in this group, their occupation and economy, and their lifestyle.

Justification for a People Group Approach

According to John D. Robb, a people group can be defined as a significantly large group of individuals who perceive themselves to have "a common affinity for one another because of their shared language, religion, ethnicity, residence, occupation, class or caste, situation or combination of these."1

S. D. Ponraj points out that "there are 4635 people groups in India. Among these, there are 389 Christian communities, which is 7.3 percent and the rest of the people groups are unreached." 2

Generally SDA evangelistic crusades aim at all people who will attend a series of meetings. For a church that preaches the everlasting gospel to all kinds of people, this is acceptable. However, in a country where the caste system is so entrenched, it is difficult to get all kinds of people

${ }^{1}$ John D. Robb, Focus! The Power of People Group Thinking (Lalgarh, Bihar: MARC, 1994), 8.

${ }^{2}$ S. D. Ponraj, Pioneers of the Gospel Mission (Madhupur, Bihar: Education Books, 1993), 23. 
to attend a meeting due to social considerations.

Vasantharaj says that "most Christian communication efforts are aimed at the whole non-Christian population and not at a particular people group. As a result, the message reaches none since it is for all."1

According to T. C. George, "When a church participates in evangelism among the persons of its own caste, part of the difficulty of social dislocation is avoided. New converts don't have to adjust to a new social situation." 2 If a whole group converts, the probability of dislocation diminishes. George goes on to affirm that in this kind of conversion, called people movement, new converts are surrounded by families of their own sort and will not be isolated from their kin group. ${ }^{3}$ Having a church within one's own group, with familiar forms of worship, the people will be comfortable. This type of native church will grow without depending on missionaries or mission budgets. It will have power within itself. ${ }^{4}$

${ }^{1}$ Albert S. Vasantharaj, Orissa: Church and People Group (Madras: Church Group Association, 1992), 80.

${ }^{2}$ T. C. George, "Pentecostal Church Growth in South India: Case Study IX," India Church Growth Quarterly 3, no. 1 (1981): 139 .

${ }^{3}$ Ibid.

${ }^{4}$ Ibid. 
The researcher is an eyewitness to the hurdles that the SDA Church faces and the difficulties members face. Many Adventists have publicly said that because of their faith they are not able to find suitable matches for their marriageable children. They often suffer persecution from the rest of their community. Some become isolated from their family and eventually leave the church.

On the other hand, if they are evangelized within their cultural groups and customs, syrian converts can be a powerful agency to evangelize not only their own group but also the non-Christians because of their influence in Kerala. While there are serious impediments to evangelizing Hindus, among the Syrians there are no such restrictions. Iitigation going on between the syrian orthodox and the Malankara Syrian Orthodox has caused a large number of believers to join the Pentecostal Church since 1913, particularly from 1958 onward. The SDA Church has not seized the opportunity to evangelize this group. This strategy can become a model to reach the St. Thomas Christians.

Location and Numbers

The St. Thomas Christians are mostly found in central and northern Kerala. Pallipad is located in the central 
part of Kerala, about $3 \mathrm{~km}$. east of Haripad, which is the main town, and about $35 \mathrm{~km}$. southeast of Alleppey.

The population of Pallipad is 23,606 within an area of 16.93 square kilometers. Of these, 55 percent are Hindus and 45 percent are Christians. The distribution of the various Christian groups is shown in table 1.

Out of this total population, 4,355 are between 60 and 70 years of age; 3,850 are between 50 and $60 ; 3,615$ are between 20 and 30; and 4,235 are between 15 and 20 . Literacy is 100 percent among this group, while the total of the state is 97.59 percent. ${ }^{1}$

\section{TABLE I}

RELIGIOUS AFFILIATION: PALLIPPAD

1. Hindus

55

2. St. Thomas Christian Orthodox

20

3. St. Thomas Mar Thoma

13

4. St. Thomas, Pentecostals

10

5. Latin Catholics

6. Church of South India

5
0
3
0
1
1

Source: G. Mohan, Upper Division Clerk, Pallippad Panchayat, interview by author, June 23, 2000.

${ }^{1}$ Malayala Manorama Year Book, 636. 
As of 2000, in this target area there are six primary schools, one high school, two upper primary schools, one primary health center, one government hospital, one government Ayurvedic dispensary, one government homeopathy dispensary, and two private hospitals. ${ }^{1}$

\section{Occupation and Economy}

The St. Thomas Christians of Pallipad are predominantly agriculturists. From generation to generation they cultivate their land after the fashion of their forefathers, with a full knowledge of the local conditions of the rainfall and seasons, manure, nature of the soil and its fertility, and rotation of crops. Land is valuable and land ownership is a sign of respectability and is, therefore, highly desirable. ${ }^{2}$

The main activity in this area is growing rice and coconut. Other products are areca nut, cassava (tapioca), banana, ginger, pepper, and vegetables of different varieties.

A good number of people in this target area are skilled workers, industrialists, and government employees.

${ }^{1}$ Suchitra Sakthidharan, Panchayat President, interview by author, April 13, 2000.

${ }^{2}$ Aiya, 3:178. 
Many become school headmasters, managers, directors of government offices, firemen, executives, and clerks. ${ }^{1}$

The economy in this area is largely dependent on agricultural income. Apart from that, income from work abroad (in the Gulf States or the United States) and local employment also help the economy. Though unemployment is prevalent in this area, 30 percent of the St. Thomas Christians in this area are above average economically. Another 50 percent are middle class people and 20 percent are laborers and economically backward. However, the community as a whole is noted for its ability. To improve their economic standard, those who are economically backward engage in vending of various types, small scale industries, and raising ducks, chickens, or cows.

Although Hindus and Christians live in relative harmony, their economic level and culture differ according to the occupation that they hold. For example, there is a marked difference between a government officer and a poor agriculturist Iifestyle, and between a common man and the people working in Gulf countries.

${ }^{1}$ Donald A. McGavran, Understanding the Church in India (Bombay: Gospel Literature Service, 1979), 55. 
Their Lifestyle

According to Donald McGavran, "Syrian Christians, like all denominations whose members are born into the church, have their fair share of nominals. They may have no consciousness of their need for a Savior, no intention of considering the Bible [as] their rule of faith and practice; but still maintain that they are good Christians." ${ }^{1}$ He goes on to say that Syrian Catholic and Orthodox churches would be considered by most protestants doctrinally corrupt. They have borrowed many customs and beliefs from the Nambudri Brahmans, Nairs, and other Hindus, to say nothing of European and Near Eastern corruptions. ${ }^{2}$ "Though they don't think as a caste, they have conformed . . in the pattern and practices governing a caste society. As to marriage inside the Syrian community, they prefer it and mean to continue it." ${ }^{3}$

David Daniels holds the view that the Christianized Brahmins and Nairs retained their customs and habits even after changing their religion to Christianity. This was

$$
\begin{aligned}
& \text { 'Ibid., } 55 . \\
& { }^{2} \text { Ibid., } 56 . \\
& { }^{3} \text { Ibid., } 4 .
\end{aligned}
$$


done to guard and determine a person's status and function in society. ${ }^{1}$ The same is very true in this target area.

In these traditional churches the birth of a male child is announced by a Kurava sound (a shrill sound made with fingers moved up and down in the mouth). When a child reaches three years of age, he is taken to a Hindu teacher, who guides the child's fingers to write Hari Shri

Ganapathaye Namah (Glory to Ganapathy [a Hindu god]) in rice heaped on a brass plate, before a lamb. ${ }^{2}$ This is then changed to write Thriyeka Daivathinu Sthuthi (Glory to the Triune God).

Along the same lines, before a young man or a young woman leaves to get married, he or she gives a gift of betel leaf and areca nut to a guru or the eldest relative. "The bridegroom ties a Tali or Minnu (a spear-shaped gold ornament with beads arranged like a cross in odd numbers, eleven or thirteen), around the neck of the bride" ${ }^{3}$ and presents her with a Manthra Kodi (marriage dress which has Hindu ritual connection).

Pulakuli (a purification bath) followed by Qurbana for 40 days, feasts on behalf of the dead, the observance of

\footnotetext{
${ }^{1}$ K. N. Daniel, 36-48.

${ }^{2}$ Ibid. , 48 .

${ }^{3}$ Ibid. , 48 .
} 
Sharadham $^{2}$ (prayers followed by feast) on the death anniversary of the dead are other Hindu social customs they practice. $^{2}$

The St. Thomas Christians, as do others in their area, consult astrologers to ascertain muhuratam (auspicious moment) before starting a business, marriage, or a journey. They also practice the use of horoscopes and consult with Kaniyan (local expert in Hindu practices) as do the Hindus. ${ }^{3}$ When I was 7 or 8 years old I had a miraculous escape when my small boat capsized in a lake 18 feet deep. Later, my relatives said that the Valiyappachen (the dead great grandfather), who was always with the grandchildren, had protected me. Even today the appachen (grandfather) can invoke the presence of Valiyappachen for the healing of sickness or when supernatural power is needed. This concept is practiced in saints' worship where the Syrians make Kurishadi (a shrine with a cross on the top) and put the offering and invoke blessings through the departed souls of a bishop or a Metropolitan who has died. Stephen Neill rightly noted: "They have assimilated many of the social

\section{${ }^{1}$ Ibid.}

${ }^{2}$ L. W. Brown (1980), 198, 205.

${ }^{3}$ Ibid. , 205. 
customs and practices of the land and as a result they have lost the identity which was given by the apostle."1

The target group, living in one of the centers of the St. Thomas Christians, follows many of these practices.

\section{Preevangelism Period}

The preevangelism period begins with planning. It also includes the formation of the necessary committees. Preevangelism also entails building relations with authorities and people in the target area and meeting felt needs of the population. During this time SDA media activities are promoted. The whole of the preevangelism stage is accompanied by prayer.

\section{Planning the Evangelism}

Proper planning is needed in all these three phases of the evangelistic program. By the aid of the Holy Spirit, prayer, and dedication, in consultation with the mission officers and department directors, the planning takes place. Ellen White's counsel on planning is:

Well-defined plans should be freely presented to all whom they may concern, and it should be ascertained that they are understood. Then require of all those

\footnotetext{
${ }^{1}$ Stephen Neill, A History of Christianity in India
} (London: Cambridge University Press. 1985), 1:191. 
who are at the head of the various departments to cooperate in the execution of these plans. ${ }^{1}$

Plans must be based on the purpose and objectives one desires to reach. Plans must be carefully laid for resources, both financial and human.

\section{Purpose and Objectives}

Every strategy must have its purpose and objectives. These are the basis for all other aspects of the strategy. The purpose of this strategy is to raise a group of people who will fulfill the five purposes Rick Warren posits for a church: (1) outreach, (2) worship (3) fellowship (4) discipleship, and (5) service. ${ }^{2}$

The basic aim is to lead a group of St. Thomas Christians to accept the Adventist teachings and train them for discipleship and church planting among their own people, to establish an organized church with a group of 100 to 125 people, to establish a school for the children, postbaptismal care, and development activities in the community.

${ }^{1}$ Ellen White, Evangelism (Washington, D.C.: Review and Herald, 1974), 94.

${ }^{2}$ Rick Warren, The Purpose Driven Church (Grand Rapids: Zondervan, 1995), 103, 119. 
$\underline{\text { Resources }}$

The financial resources for this project will be the section (mission) evangelism fund, Global Mission fund, and local sponsors making a total of Rs.150,000. Of these Rs.25,000 are for preevangelism, Rs.100,000 for the actual crusade, and Rs.25,000 for follow-up programs.

\section{Formation of Committees}

The various committees chosen have tremendous impact on the crusade and, consequently, on its result. When the team members are guided and properly organized in committees, they can coordinate various components of the crusade in such a way that each committee feels the responsibility of working together for a rich harvest. Ellen White points out:

The secret of our success in the work of God will be found in the harmonious working of our people. There must be concentrated action. Every member of the body of Christ must act his part in the cause of God, according to the ability God has given him. We must press together against obstructions and difficulties, shoulder to shoulder, heart to heart. ${ }^{1}$

The ministerial secretary will be coordinator of the evangelistic program. All committees will report to the coordinator.

${ }^{1}$ Ellen G. White, Christian Service (Washington, D.C.: General Conference of Seventh-day Adventists, 1947), 75. 
In order to have a spirit of responsibility, a smooth and successful evangelistic crusade, the following committees are set up.

\section{Steering Committee}

In all the major evangelistic crusades it is indispensable to have a steering committee which will function from the planning stage. This committee is composed of chairpersons of all the committees and is chaired by the coordinator of the evangelistic program.

The duties include:

1. Control the general program of the crusade

2. Maintain order of the program

3. Meet every morning or evening to evaluate progress

4. Tap resources for the progress of the program

5. Be answerable to higher authorities.

\section{Finance Committee}

The main responsibility of the finance committee is to create a budget for the crusade and keep the costs within that budget, remembering that 25 percent of the budget is for postbaptismal care. The chairperson of this committee will be someone who has a knowledge of finances and is a good steward. Financial resources and transactions will be made known to all the committees; there will not be anything secret, in order to win the confidence of each committee. 
The finance committee will also be in charge of raising funds. The chairperson of each committee will be a member in the finance committee. A bank account will be opened in the name of the crusade. All money will be spent with the approval of the committee and bills will be signed and countersigned.

Within the finance committee, there will be a secretarial subcommittee to collect the daily offering and report to the main committee. This subcommittee is responsible for keeping all bills as they come from various committees.

\section{Pandal or Hall Committee}

The place of meeting is most important. There is no hall available, hence a pandal will be erected. In consultation with the finance committee, the Pandal Committee will choose an ideal place and have a pandal or shed erected. The Pandal Committee will also be in charge of procuring chairs and other equipment needed for the crusade.

The pandal will be seventy-five by forty feet with a capacity of 500-600 seats. While the chairs will be rented, a few chairs, tables, and other articles for future use in the church will be purchased. The finance committee will assist in these matters. The pandal will be ready to use 
two days before the crusade. This will be done with the help of lay members already incorporated into the program.

This committee will take care of government permission for the use of sound amplifier, electric connection, emergency light, generator, kerosene, and gas lights.

\section{Publicity Committee}

The publicity committee will function at least three months prior to the actual crusade. Publicity in its various forms is one of the most important aspects of the evangelistic crusade. Attendance at the public meeting is largely dependent on the advertising used in the target area. In harmony with the taste and culture of the population, the following publicity will be given.

Television

The use of television in this area is effective due to the fact that many homes have TV sets. The best time to advertise through the TV is between 9:30 and 10:00 p.m., when everyone is watching. As the target group already knows Mark Finley's program, a timely advertisement will catch their attention.

Radio

Radio is another powerful medium through which the crusade will be announced. As the target people are already 
listening to the Adventist messages in various languages, this advertisement will encourage them to listen to the messages, live, near their homes. Care will be taken to fulfill the promises made through the media.

Personal invitation

Though advertising can be done by radio and television, in Kerala personal invitations are still the best way to advertise. The personal invitation is done in door-to-door visitation with attractive handbills. Not only do the visitors invite people, they pray in their homes and explain the meetings.

Posters and banners

Another way to advertise the program is through posters with photographs of the main speaker. Banners can also be used. The posters and banners are made and placed so that they will catch the attention of the people.

\section{Newspapers}

Newspapers will be widely used in Kerala to advertise the evangelistic crusade. A press conference will be called to advertise in the major papers of the target area. These will include the speaker's photo, as well as the time, place, and date of the meeting. 


\section{Transportation Committee}

This committee will function throughout the crusade. This committee will work with the government transport authorities and make necessary negotiations to bring the people to the meeting place and take them back. This committee is also responsible for taking the baptismal candidates to the baptismal site and returning them to their village.

\section{Bible-Marking Plan Committee}

This committee will be in charge of the Bible-marking plan. It will also handle registration, daily attendance, collecting and rearranging Bibles, and other matters of attendance. It is also in charge of song books, tracts, and other items used during the campaign. It will be in charge of the sales counter.

\section{Visitation Committee}

In Adventist evangelistic crusades in Kerala, success to a large extent depends on the visitation work. Each visitation team must be well instructed, informed, and counseled. Ten teams of two (a pastor and a lay person) will be engaged at least thirty days prior to the actual crusade. They will be well trained under able leaders and equipped with all necessary materials on St. Thomas Christians to be used in homes. From the beginning, a 


\section{5}

specific territory will be assigned to each team. The visitation committee will ensure that these teams function well and the needed guidance is given. At times the leaders will also visit people, to clear any doubt and to help prepare them for baptism.

\section{Music Committee}

Music is the heart of the evangelistic crusade in Kerala. Music is a powerful means to attract people to meetings. The music will be in native style, as that is preferred by this group. Congregational singing will be emphasized, in keeping with the taste of the audience.

Adventists have at least two orchestra groups available for such crusades. They will perform in exchange for food and transportation.

Ellen white has written much about the role of music and its proper use. She supports instrumental music and stresses good singing:

Music should have beauty, pathos, and power. Let the voice be lifted in songs of praise and devotion. Call to your aid, if practicable, instrumental music, and let the glorious harmony ascend to God as acceptable offering.

\footnotetext{
${ }^{1}$ White, Evangelism, 505.
} 
Platform Committee

A platform committee will be responsible for the daily arrangement of the platform. They will prepare the order of service and will arrange for persons to go to the stage with the speaker to announce songs, prayers, and the offering. They will also help the speaker by reading the Bible.

\section{Health Committee}

The health committee will function before, during, and after the crusade. This committee will be responsible for arranging free medical clinics, health talks, and classes on nutrition, first aid, drugs and alcohol, and vegetarianism. They will also coordinate five-day plans to stop smoking, temperament seminars, and cooking schools before, during, and after the crusade.

On the role of medical evangelism, Ellen White says:

Nothing will open doors for the truth like evangelistic medical missionary work. This will find access to hearts and minds, and will be a means of converting many to the truth. . . Medical missionary work is the right, helping hand of the Gospel, to open doors for the proclamation of the message. . . . A demonstration of the principles of health reform will do much toward removing prejudice against our evangelical work. ${ }^{1}$

\footnotetext{
${ }^{1}$ Ibid., 513-514.
} 


\section{7}

Usher Committee

The usher committee is vital to the evangelistic

crusade. The warm and hearty welcome that people receive at the gate of the pandal will make them more open toward the gospel. The responsibilities of this committee are to:

1. Greet people at the gate and see that they are seated comfortably

2. Maintain order and neatness in and around the pandal

3. Maintain order and discipline during and after the meetings

4. Usher people out after the meeting so they can greet the speaker at the exit

5. Function as security force during the meetings.

Baptismal Committee

The baptismal committee will organize baptismal classes to prepare the candidates well in advance of the baptism. There may be candidates who need to get permission for baptism and solve various other problems. This committee can look into such matters and counsel the candidates appropriately.

They will arrange for the baptismal gowns, certificates, and a proper site for baptism. They will make arrangements for the fellowship lunch and transportation in 
consultation with the transportation committee. They will also arrange for a communion service after the baptism.

\section{Building Relationship with Local Authorities and People}

The success of any strategy depends largely upon the public relations campaign. Soggard says, "The primary purpose of public relations is to facilitate a smoothrunning operation. It is a matter of establishing and safeguarding the right relationships."

Through friendship we communicate ideas. Pallippad constitutes an unreached area. In addition the people have the preconceived idea that Adventists are the false prophet of the last days, followers of Jews, false teachers, or Jehovah's Witnesses. Through friendship these concepts can be rectified and the people motivated to come see what Adventists are. The Adventist message is diametrically opposed to most of these groups' concept of Christianity. When good relationships are forged with both the public and the local government authorities, Adventists will be helped if opposition arises.

Felt-Needs Evangelism

Christians should address different types of felt needs. When Jesus Christ ministered on earth, He addressed 
all types of felt needs. "The blind receive their sight, the lame walk, the lepers are cleansed, the deaf hear, the dead are raised up, and the poor have the Gospel preached to them" (Matt 11:5).

The Scriptures promote meeting people's physical as well as spiritual needs. The Bible commands believers not only to speak about the love of God but also to show this love through good works (Gal 6:10, John 3:17-18). The feltneeds approach to evangelism was shown by the Lord Himself. ${ }^{1}$

The immediate felt need of an individual must be met by a Christian brother. Dudley observes that

by meeting people on the level of their felt needs, even when they appear to have little relation to religion, the church has opportunity to demonstrate love and care. People establish a contact with the church and take the initiative to come to an event, it conducts. They have overcome barriers of uncertainty, suspicion, and apathy. The way opens for them to become more fully involved in the life of the church and eventually walk down the path to full membership. ${ }^{2}$

Felt needs are met through various programs. Most address physical needs of the local people.

${ }^{1}$ Tom A. Steffen, Passing the Baton: Church Planting That Empowers (La Habra, Calif.: Center for Organizational and Ministry Development, 1993), 131.

${ }^{2}$ Roger L. Dudley and Des Cummings, Jr., Adventures in Church Growth (Washington, D.C.: Review and Herald, 1983), 87 . 
ADRA (Adventist Development and

Relief Agency)

ADRA, one of the agencies of the church, views

development as an integrated process which addresses "the basic sources of poverty, seeking to build self-reliance in the individual and equitable social relationships without reference to ethnic, political, or religious associations."1

Certain ADRA projects can uplift the standard of living of the community by providing employment through incomegenerating projects such as goat and dairy farming. This will help the ministry in many ways. When other churches fail in such programs, people will be attracted to the SDA Church. In addition, the poor will be encouraged to accept Adventism. This will be done according to the carefully assessed needs of the community. If the church could meet needs of the people, it would become the center of the community. As a result, the church would be able to win people to Christ without social and cultural dislocation. A drinking water project for Rs.157,000 is already voted for this target area and work is now in progress. It will help fifty families to solve their drinking water problem and in turn will boost evangelism in the target area.

${ }^{1}$ J. R. L. Astleford, ADRA Southern Asia Manual (Hosur, Tamil Nadu: Jeevan Jyothi, 1991), 13. 
Five-day Plan to Stop Smoking

In this community thousands of adults are tobacco addicts. The SDA Church has already conducted one five-day plan in a nearby place and about ten people stopped smoking. There are plans to conduct this program in fifteen to twenty places before launching the evangelistic crusade. The evil effects of smoking are taught, hand bills are distributed, and the mechanical smoker is used to explain the effects of smoking.

\section{Eree Medical Services}

In order to attract people and build good relations with the public, health courses will be conducted in community halls or other appropriate locations. This will not only provide health education, but also prepare people to attend the meetings when they commence. Free medical checkups will be made available to arouse the interest of the people.

\section{Youth Programs}

Youth retreats, clubs, sports, and various other activities will be organized in different parts of the target area to interest youth and to provide them with healthy relationships and friendship with Christ. The ultimate aim will be to develop in them a practical 
spirituality which will make them leaders in evangelism, social renewal, and commitment to Christ.

SDA Media Promotion

At this time SDA media will be promoted among the target group. The Voice of Prophecy (VOP) and other Adventist programs, both on radio and television, will be publicized.

\section{VOP Enroliment and Rally}

Church members from the Mavelikara and Thattarambalam churches will visit all the homes to invite persons of the target group to enroll in the VOP courses for youth or adults. This will acquaint them with the Bible and also remove prejudices toward the Adventist Church. Team members will collect the lessons and send them to the school, get them corrected, and personally return them with the following lesson. Once a number of persons have completed their lessons, there will be a graduation service and a VOP rally.

\section{Adventist World Radio}

In 1999 Adventist World Radio was broadcasting "more than 1,000 hours per week"1 in more than 40 languages. Some

${ }^{1}$ Adventist World Radio Advertisement, 1999, Silver Spring, Maryland. 
105 hours a week cover India in 14 languages, including Malayalam, the local language. ${ }^{1}$ Program in Malayalam is every day from 8:30 to 9 p.m. The program covers the Adventist message, beginning and ending with a song which attracts the people. Program cards will be distributed in the homes while visiting the houses, during the five-day plan, the youth program, for VOP enrollment and rally, and during the public meeting.

\section{Television}

Many of the homes in the target area have cable television. People who do not have this facility can watch programs in their neighbors' homes. As part of the preevangelism program, people will be invited to watch Mark Finley on television. The program is aired for 30 minutes once a week through Adventist Television Network on Saturdays from 5:30 to 6 p.m. It is only in English, which limits the audience to the educated group. But the language is simple enough that most people will understand. The Malayalam version of this program is almost ready to be used. However, the English programs can still attract the attention of people.

${ }^{1}$ Adventist World Radio, "Programme Schedule, 29 March to 24 October, 1999." 
Bible Studies

The preevangelism activities and emphasis on Adventist media will create an awareness of the existence of Adventists. They will also create interest in knowing more about what the Bible teaches.

Those who are interested in studying the Bible will be incorporated into Bible study groups that will function as cell groups in private homes. Those will be directed by trained team members. After one month of study, using the evidences of Sabbath keeping among St. Thomas Christians, some of those who have studied may make a decision for Christ and be baptized. Immediately they will be incorporated into the evangelistic team to work for the targeted area.

\section{Prayer Preparation}

Satanic strongholds influence churches and individuals today. In order to gain victory, these strongholds must be pulled down. The real source of success is

the power of God in answer to prayer, first to open doors of access, then to raise up and thrust fort laborers and then to break down all opposition and make the truth mighty in converting, subduing, saving and sanctifying. ${ }^{1}$

\footnotetext{
${ }^{1}$ Robb, 33 .
} 
Jesus conquered the power of Satan through fasting and prayer (Matt 4:1-10). Each program in the target area will be bathed in prayer.

Power encounters are "healings, deliverance or any other visible, practical demonstration that Jesus Christ is more powerful than the spirits, powers, or false gods, worshipped or feared by the members of a given people group." ${ }^{1}$ The genuine experience of the power of the Holy Spirit, providing relief from various problems such as sickness, business failure, and family problems will be one of the main thrusts in this target area.

Prayer results in church growth, genuine worship, and financial stability for the church. This was the method that Jesus used and commissioned His disciples to use. The apostle Thomas is said to have used prayer in India. This use of the genuine gift of the Spirit appears to be lacking in the Indian SDA Church, particularly in Kerala.

During both the preevangelism and evangelism stages, regular prayer sessions will be held. While Bible studies are being conducted, cases of sickness, satanic attack, and family problems, all common in this target area, will surface. The relief from such problems by the genuine

${ }^{1}$ Charles H. Kraft, "What Kind of Encounter Do we Need in Our Christian Witness?" Evangelical Mission Quarterly 27 (July 1991) : 259. 
working of the Holy spirit not only will lead people to accept the truth but also will remove prejudiced attitudes that SDAs are not Christians. Prior to the actual commencement of the crusade, there will be three days of fasting and prayer.

Ellen White suggests how to go into the conflict: With heart searching, confession of sin, and earnest prayer, and often fasting for a time, they should entreat that God would especially help them and give His saving, precious truth a glorious victory, that error might appear in its true deformity and its advocates be completely discomfited. ${ }^{1}$

This fasting and prayer will meet various needs of the evangelistic crusade:

1. To overcome organizational obstacles,

2. To release the target area from satanic oppression,

3. To have a large attendance,

4. To foster a positive attitude towards truth,

5. To request the guidance and power of the Holy Spirit,

6. To create unity among the workers,

7. To be shielded from satanic attack,

8. To strengthen the speaker with the message and power of the Holy Spirit,

${ }^{1}$ Ellen G. White, Testimonies to the Church, 9 vols. (Mountain View, Calif.: Pacific Press, 1948), 1:624. 
9. To request smooth function of the light and sound systems,

10. To be protected from sickness and accidents, 11. To have a rich harvest.

\section{Public Meeting Period}

After completing the preevangelism activities, the team will be ready to launch an evangelistic crusade for twentyone days, on the selected site.

\section{Daily Program}

The team members will live in a rented house. Breakfast and supper will be arranged for with a nearby hotel, and lunch will be on the way as they go for the Bible studies. Supper will follow the meeting for which they are given daily allowance of Rs.85 including local travel.

Pastors and local lay members are incorporated into teamwork. The evangelism team's program will commence at 6 a.m. Personal devotion, breakfast, and morning devotions will be over by 9 a.m. From 9 a.m. until 4 p.m. team members will go house to house visiting and giving Bible studies based on the subjects presented, meeting the spiritual needs of the community by praying for people, and healing of the sick. They will return to their place to rest at 5:00 p.m. They will go to the meeting place ready for the song service at $6: 45 \mathrm{p} . \mathrm{m}$. At $7 \mathrm{p} . \mathrm{m}$. the stage will 
be ready to give the health message prepared by the health committee, followed by the Bible message at 7:30 p.m.

After the message is presented there will be an altar call for listeners to commit their lives to Jesus and to the message that was presented. There will be special prayer for the sick and for various other needs of the people, followed by a film show. The day's work will end with an evaluation and a final prayer.

\section{Opening Night}

All team members know what they are to do. The highlight of the opening night should be the inaugural program. A national leader or a church leader will be invited for the inaugural address and program. Adventist work around the world will be showcased. There will be television, radio, and newspaper reporters so that the occasion will be advertised on the following day in the media. The guest speaker and other prominent persons will be honored with gifts. The Bible and other related literature on Adventism and a handbill will be presented to the guest speaker. Following this there will be a short but powerful message on seven wonders of the Bible with a short introduction of the St. Thomas Christians and their use of Scriptures. 
Topics Covered

1. Seven Wonders of Bible; The St. Thomas Christians and their use of the Bible

2. The Origin of Evil

3. Dan 2; St. Thomas Christians and their Messianic hope.

4. Prayer; St. Thomas Christians and their prayer practice.

5. Who is Jesus Christ? St. Thomas, his experience with Jesus and his commission.

6. Second Coming; The relevance of the Second Coming to St. Thomas Christians.

7. Signs of the Second Coming; The relevance of st. Thomas teachings today (Matt 24:14).

8. Repentance or Salvation; St. Thomas Christians then and today and the need for change.

9. Ten Commandments; St. Thomas Christians, the early church.

10. Sabbath, Biblical and Historical; St. Thomas Christians.

11. Sunday Observance (eight references in the Bible), History of the inception of Sunday worship, and the st. Thomas Christians.

12. Seal of God and Mark of the Beast; Relevance to St. Thomas Christians today. 
13. Temperance; St. Thomas Christians and their practice of healthful living.

14. Baptism; St. Thomas Christians, evidences.

15. The Ministry of the Holy Spirit in the life of st. Thomas; the need for gift-based ministry, early church experiences.

16. Tithe; How the St. Thomas Christians supported the church.

17. State of the Dead; St. Thomas Christians and their belief.

18. Faith and Worship; St. Thomas Christians (Humbled Cross Oath).

19. Judgment and St. Thomas Christians.

20. Three Angels Message; relevance to St. Thomas Christians today.

21. Remnant Church and St. Thomas Christians; The final call.

These doctrinal topics will be presented in such a way that will connect to the faith and practices of St. Thomas Christians then and today. There will be a call to personal commitment and an emphasis on the need of Jesus in their lives. 
Baptism

The Baptismal Committee plays a key role in the preparation of the candidates for baptism. The team members and all others connected with the crusade will assist in preparing candidates for baptism. The first baptism will take place one week before the last saturday of the meetings.

\section{Preparation}

The list of the individuals who are ready for baptism will be prepared. Proper care will be taken by the baptismal committee so that each candidate understands and accepts SDA teachings.

The candidates prepared for baptism will be brought to the meeting place on the Sabbath morning with prior instruction about clothing after baptism. During Sabbath School there will be a special baptismal class for the candidates. Before the worship service the baptismal candidates will be seated in front of the audience. After the worship service is over the officiating minister will make the baptismal examination of the candidates. They will be given a special welcome, and their relatives or friends who came to witness the ceremony will be acknowledged. As soon as the service is over, the arranged transportation will take them to the baptismal place. 


\section{Ceremony}

The ceremony will take place in a river nearby. A gown will be provided for each candidate. Prior arrangement will be made at the riverside for the smooth and solemn function of the ceremony, which will be conducted by the designated ordained ministers. The service will start with singing while the candidates are ushered into the water and start with a prayer. The ceremony will close with an invitation for others to commit themselves to baptism in the next ceremony.

Following the baptism there will be a fellowship meal. After this, the candidates will be accepted into church fellowship.

\section{Postbaptismal Care}

In the past, evangelistic crusades were a partial failure due to the lack of postbaptismal care. Michael Green shows the importance of postbaptismal care in the following words: "After-care is as vital as birth. If not cared for, the new babe in Christ will starve." ${ }^{\text {Ellen }}$ White also stressed this necessity: "The zeal of many ministers seems to fail as soon as a measure of success attends their efforts. They do not realize that these newly

${ }^{1}$ Michael Green, Evangelism--Now and Then (Leicester, England: Inter-Varsity Press, 1979), 81. 
converted ones need nursing, watchful attention and help, and encouragement." 1

White also affirms:

No wonder that some become discouraged, linger by the way, and are left for wolves to devour. . . There should be more fathers and mothers to take these babes in the truth to their hearts, and encourage them, to pray for them, that their faith be not confused. ${ }^{2}$

Items to be included in postbaptismal care are worship services, a school for the children, and the creation of a Life Development Institute. To strengthen the congregation, cell groups will be implemented. Finally a church building will be constructed.

\section{Worship}

The quality of these new members and the future of the church depends on postbaptismal care, which involves various activities. The most important is instituting regular worship and securing an active pastor. In the Adventist church, particularly in Kerala, worship is dry. James A. Cress rightly says:

Our typical order of worship today is neither biblical nor Adventist. Instead we follow a nineteenth-century style that relegates worship roles to platform leaders and spectator roles to the congregation. There is little active participatory involvement of each worshipper with the Creator. The dynamic and vital

\footnotetext{
${ }^{1}$ White, Testimonies, $4: 68$.

${ }^{2}$ Ibid.
} 
encounter between Creator-God and worshiping penitent is too often absent. ${ }^{1}$

The systematic worship of God is most important; Sabbath worship will be organized in such a way that each member will be spiritually edified and strengthened, as was the practice of the early Adventist Church. On this Cress observes: "The worship style of early Adventist believers was quite expressive, nearly Pentecostal in nature."2

Cress emphasizes the need for "increased audience participation in scripture reading, prayer requests, and testimonies." 3 In Kerala there should be active singing and clapping of hands to make the worship more participatory. Thus family and group ties will be strengthened.

\section{School for the Children}

In many places where work was started among the St. Thomas Christians, it has not progressed. One of the main reasons is that the initial enthusiasm, the fervor, and the proper guidelines were not followed. Ellen white says:

The good seed sown in these meetings should not be left to perish for want of care. Many parents would rejoice, if the instruction given to their children at the camp-meeting could be continued. They would gladly place their children in a school where the same 1995, 29.

${ }^{1}$ James A. Cress, "Worship Is a Verb," Ministry, June ${ }^{2}$ Ibid.

${ }^{3}$ Ibid. 
principles were taught and practiced. While the interest of both parents and children is awakened, it is a golden opportunity for the establishment of a school at which the work began at the camp-meeting can be carried forward. ${ }^{1}$

White goes on:

And as believers are raised up and churches organized, such a school will be found of great value in promoting the performance and stability of the work. . . All necessary arrangements should be made for the permanent establishment of the church school. ${ }^{2}$

As this fact is well understood, a church school will be established in which "the children and youth could receive a true education," ${ }^{3}$ where "they can be disciplined and trained for God's service." 4

\section{Life Development Institute}

The main source of learning for the new members will be the "Life Development Institute." This institute will offer a wide variety of opportunities for spiritual growth. Bible studies, Daniel and Revelation seminars, workshops, and independent study programs will be arranged. The Adventist prophetic message will be thoroughly taught so that members do not deviate from the truth.

${ }^{1}$ White, Testimonies, 6:107-108.

${ }^{2}$ Ibid.

${ }^{3}$ Ellen G. White, Child Guidance (Washington, D.C.: Review and Herald, 1982), 310.

${ }^{4}$ Ibid. , 316 
Mid-week worship services will be a vital part of the Life Development Institute. In order to have a spiritual awakening, from time to time the church will invite outstanding evangelists and special evangelistic meetings will be conducted. Non-Christians will also be welcomed, though the primary objective of the program is the strengthening of church members.

\section{Cel1 Groups}

While the Life Development Institute does its work, the new congregation will be organized. Intensive evangelism should continue in the target area and nearby. In time this congregation will be ready to establish another church. Having such a goal in mind, an evangelistic program will be designed.

The cell group (home church) is an excellent way to encourage church growth and multiplication. The program does not need a large budget or skills in public evangelism.

Most people attend church, not because they understand and accept all the doctrines, but because it offers them a Christian support system. Ritchie way says that "the home group setting provides more fellowship than the regular church setting, - . which requires sharing, warmth, caring, and healing, . . free discussion and 
involvement." ${ }^{1}$ He notes that home group meetings help in three areas: "the inreach in which God reaches into people through His word, the outreach in which people reach out to people through witness, and the upreach in which people reach up to God through prayer." 2

When new believers come to the Adventist Church, they want answers to their prayers, the protection of God in their lives, and explanations for supernatural phenomena. All this can be successfully done in the cell group. The small group, with some six to eight members, is an ideal place for knowing Christ through Bible study, because people are personally involved in the process. Such Bible study will not only give practical knowledge of Jesus but also will help people know Jesus personally and grow into a mature Christian life and promote evangelism.

Ellen white observes: "The formation of small companies as a basis of Christian effort is a plan that has been presented before me by one who cannot err. If there is a large number of the church, let the members be formed into small companies, to work not only for the church members but for unbelievers also." ${ }^{3}$

\footnotetext{
${ }^{1}$ Ritchie Way, "Home Group Ministry Helps Your Church Grow," Ministry, February 1992, 10.

${ }^{2}$ Ibid.

${ }^{3}$ White, Evangelism, 115.
} 
The example of Paul Yonggi Cho, pastor of the world's largest church, in South Korea, proves that cell group ministry is successful.

We have 50,000 cell groups, and each group will love two people to Christ within the next year. They select someone who's not a Christian, whom they can pray for, love, and serve. They bring meals, help sweep out the person's store--whatever it takes to show they really care for them. When the person asks, "why are you treating me so well?" our people answer, "Jesus told us that we're supposed to do good to all men, and we want you to know that we love you, and so does Jesus. After three or four months of such love, the hardest soul softens up and surrenders to Christ."1

\section{Church Building}

It is the responsibility of the steering committee to secure a piece of land and build a church for the new congregation. Ellen White says that the workers in new territory should "not feel free to leave their field of labor till the needed facilities have been provided for the churches under their care."2 To the St. Thomas Christians, the place of worship is very important and may never be used for any other purpose.

The congregation may be in a position to raise enough funds to erect a church. If they are not able to do this, they can raise half of the cost to be matched by funds from

${ }^{1}$ Paul Yonggi Cho, Successful Home Cell Groups (Plainfield, N.J.: Losgos International, 1981), 94.

${ }^{2}$ White, Testimonies, $6: 108$. 
the mission, union, and division. Funds may also be secured from abroad, both from Adventist and non-Adventist sources. 
CHAPTER VII

SUMMARY, CONCLUSIONS, AND RECOMMENDATIONS

\section{Summary}

There are no historical records that firmly establish the historicity of Thomas's apostolate in India. However, it is not possible to absolutely deny that apostolate which is affirmed in a variety of traditions and legends that have circulated beginning with the third century.

The St. Thomas Christians in Kerala claim their spiritual genesis from Thomas the disciple of Jesus Christ. According to tradition, Thomas came to Kerala on his second journey to India in A.D. 52. He established seven churches of Jews and native Hindus and was martyred at Mylapore in the year A.D. 72. Christianity in Kerala was further enhanced by the immigration of the merchant Thomas of Cana with 336 families (A.D. 345).

Little is known about the early teachings and practices of the St. Thomas Christians. The records available indicate that they practiced a simple faith. They had two sacraments, baptism and the Lord's Supper, and their worship was on Saturday. Sunday observance appears to have been 
introduced during the fourth century. However, the st. Thomas Christians in Kerala appear to have kept the seventhday Sabbath even until after the advent of the Portuguese and the Synod of Diamper (1599).

Until the seventeenth century the St. Thomas Christians were connected to the East Syrian Church, and their liturgy was in old Aramaic or Syriac. Their first significant contact with Roman Catholics was in the sixteenth century. The subsequent introduction of the Inquisition and the program of Latinization paved the way for the synod of Diamper (1599) and brought the St. Thomas Christians under the umbrella of Roman Catholicism.

A number of Roman Catholic practices and beliefs led to resentment and protests of the St. Thomas Christians. This climaxed in the Humbled Cross Oath (1653), when many of them broke away from Roman Catholicism.

The St. Thomas Christians in India remained united for centuries, holding the same faith that they claim was taught by the apostle Thomas. Though a certain amount of unity can still be seen among them, since the seventeenth century this community has become divided and sub-divided into various groups.

On the basis of the results of the historical investigation, a strategy for reaching the St. Thomas Christians was designed. Its basic approach is to plan and 
organize a preevangelism period and then conduct an evangelistic effort for twenty-one days in harmony with the culture and practices of the local population. Throughout the series, the St. Thomas Christian history will be used. Special attention will be paid to Sabbath observance in the St. Thomas tradition.

Proper media promotions, gift-based ministry, and Bible study for those who are interested will accompany the public meetings.

As the new congregation is formed a number of programs will strengthen their spiritual as well as social life. Apart from the regular worship of God, for spiritual edification, a school will be established for the children to be educated in the Lord's way. A Life Development Institute will offer a wide variety of opportunities for spiritual growth. A cell-group ministry will help new members grow in Christ, and a church building will be erected for regular worship.

\section{Conclusions}

While scholars may debate the historicity of the st. Thomas tradition, there is no doubt that the story of his apostolate is seminal to the early development of Christianity in India. Furthermore, in the minds of st. Thomas Christians in Kerala today, the apostle's ministry is 
authentic and the foundation of their community. Yet, in spite of their conviction that they are part of the spiritual descendence of the apostle, St. Thomas Christians are generally unaware of the teachings of the early Christian apostle and his successors. In fact, they have little knowledge of anything but the traditions regarding the miracles of the apostle Thomas.

Teaching the St. Thomas Christians about their own heritage can serve as a bridge to evangelism. Of special interest are the clear references to the observance of the seventh-day Sabbath through the centuries. When they hear their history expounded by the evangelist, St. Thomas Christians will develop an appreciation for those who are presenting the evangelistic meetings, as well as for the message preached. Furthermore, understanding their ancient beliefs will make the acceptance of Sabbath observance easier.

\section{Recommendations}

1. Pastors in the Southern Asia Division should be equipped with the knowledge of Sabbath keeping among the St. Thomas Christians in Kerala. This information should be included in the curriculum of religion and church history at Spicer Memorial College. 
2. An examination of the history of Sabbath keeping among some of the old Christian communities, such as the Coptic, Jacobites, Ethiopian, and Armenian churches, may help in approaching the people of those communities with the full Bible message. 


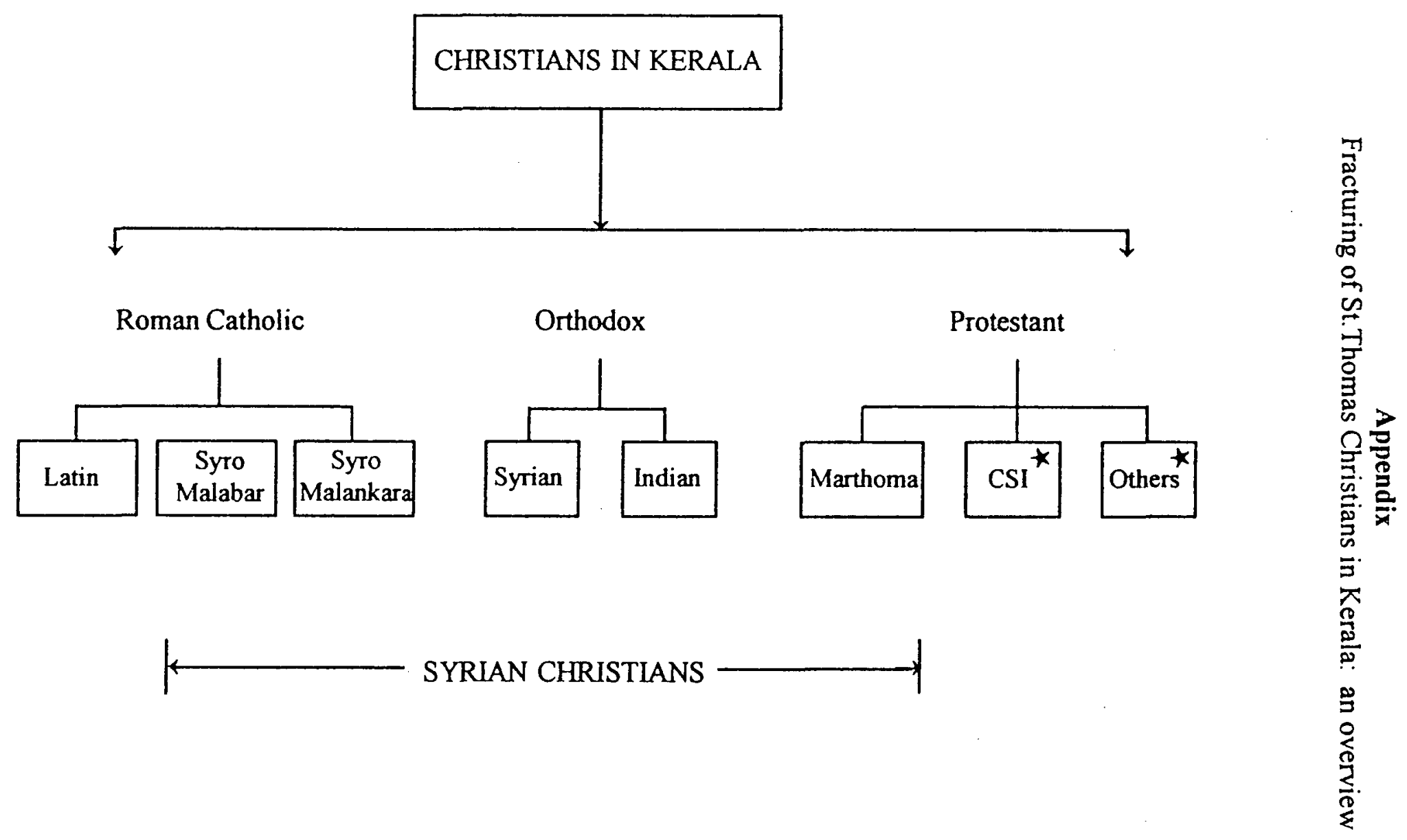

$\star \quad$ The Madhya Kerala Diocese of CSI consists largely of Syrian Christians. There are Syrians in the last category also, which is mostly fundamentalist. 


\section{BIBLIOGRAPHY}

Adeney, Walter F. The Greek and Eastern Churches.

Edinburgh: T. and T. Clark, 1908.

Adventist World Radio Advertisement Pamphlet, 1999.

Adventist World Radio. "Programme Schedule, 29 March to 24 October 1999."

Aerthayil, James. The spiritual Heritage of the st. Thomas Christians. Bangalore: Dharmaram, 1982.

Agur, C. M. Church History of Travancore. Madras: Asian Educational Service, 1990.

Aiya, N. Nagam. The Travancore state Manual. 3 vols. Madras: Educational Service, 1989.

Aprem, Mar, and T. P. Abraham. Dictionary of Church History. Kottayam, Kerala: Ashram, 1986.

Aprem, Mar. The Chaldean Syrian Church of the East. Delhi: ISPCK, 1983.

Astleford, J. R. L. ADRA Southern Asia Manual. Hosur, Tamil Nadu: Jeevan Jyothi, 1991.

Ayyar, Anantakrishna Rao Bahadur. Anthropology of the Syrian Christian. Ernakulam, Kerala: Government Press, 1926.

Bacchiocchi, Samuel. From Sabbath to Sunday: A Historical Investigation of the Rise of Sunday Observance in Early Christianity. Rome: Pontifical Gregorian University Press, 1977.

Black, Matthew. The Scrolls and Christianity. London: SPCK, 1969.

Brown, L. W. The Indian Christians of St. Thomas. Cambridge: Cambridge University Press, 1956. 
- The Indian Christians of St. Thomas. Madras:

B. I. Publications, 1980 .

Brown, Raymond E. John. Anchor Bible, vol. 29. New York: Doubleday, 1966.

Buchanan, Claudius. Christian Research in Asia. London: G. Sydney, 1812 .

Buchanan, Francis. Journey from Madras through the Countries of Mysore, Canara and Malabar. 3 vols. Madras, Asian Education Services, 1988.

Budge, E. A. Wallis. Legends of Our Lady Mary. Oxford: Oxford University Press, 1933.

Catholic Directory of Kerala. Angamaly, Kerala: P. V. Varkey and Baby Jose, 1986.

Chediath, Geevarghese. "A Voice in the Wilderness." Christian Orient Ecclesiology Book Review News 19 (March 1998): 14-19.

Cherian, C. V. A History of Christianity in India. Kottayam, Kerala: Historical Society, 1973.

Cherian, K. P., Interview by author. August 18, 1998, Pune, India.

Cho, Paul Yonggi. Successful Home Cell Groups. Plainfield, N.J.: Logos International, 1981.

Cittalai, Cattanar. Manimekalai [Tamil Epic]. Madras: Pari Nilayam, 1963.

Cress, James A. "Worship Is a Verb." Ministry, June 1995, 29.

D'orsey, J. D. Portuguese Discoveries, Dependences, and Mission in Asia and Africa. London: W. H. Allen, 1893.

D'Souza, Herman. In the Steps of St. Thomas. Madras: Diocesan Press, 1983.

Daniel, David. The Orthodox Church of India. Delhi: Printaid, 1986. 
Daniel, K. N. A Brief Sketch of the Church of St. Thomas in Malabar and the Syrian Copper Plates. Kottayam, Kerala: CMS, 1939.

Danielou, Jean. The Dead Sea Scrolls and Primitive Christianity. London: Omega, 1958.

Dellon, M. The History of the Inquisition of Goa. London: Robert Owen, 1688.

Dudley, Roger L., and Des Cummings Jr. Adventures in Church Growth. Washington, D.C.: Review and Herald, 1983.

Encyclopedia Britannica. 1946 ed. S.v. "Sunday."

Ephraem Carmina Nisibis. Translated by Edmund Beck, Corpus Seriptorum Christianorum Orientalium, 241. Louvain: Corpusco, 1963.

Eusebius Church History. The Nicene and Post-Nicene

Fathers. 2d Series. Edited by Philip Schaff and Henry Wace, Grand Rapids: Eerdmans, 1961.

Evora, Archbishop. Quoted in B. Radhakrishna Rao, "Christianity in India: A Critical Study on Inquisition in Goa." Vivekananda Kendra Patrika 8, no. 12 (1979): 169-172.

Exell, Joseph S. "Esther." The Biblical Illustrator. Grand Rapids: Baker, n.d.

Ferguson, Everett. Backgrounds of Early Christianity. Grand Rapids: Eerdmans, 1993.

Firth, C. B. An Introduction to Indian Church History. Madras: Christian Literature Society, 1983.

Fortescue, Adrian. The Lesser Eastern Churches. London: Catholic Truth Society, 1913.

Gaster, Theodore H. The Dead Sea Scriptures. New York: Doubleday \& Co., 1956.

Geddes, Michael, The History of the Church of Malabar from the Time of Its Beginning Until First Discovered by the Portuguese in the Year 1501. London: S. Smith \& B. Walford, 1694. 
George, T. C. "Pentecostal Church Growth in South India, Case Study IX." India Church Growth Quarterly 3, no. 1 (1981) : 136-139.

George, V. K. The Holy Church of the East and Mar Nestorians. Trichur, Kerala: Narsai, 1959.

Green, Michael. Evangelism--Now and Then. Leicester, England: Inter-Varsity Press, 1979.

Hambye, E. R., and C. M. I. Perumalil. Christianity in India: A History in Ecumenical Perspective. Bangalore: St. Paul, 1972 .

Hiebert, Paul G. Anthropological Insights for Missionaries. Grand Rapids: Baker, 1988.

Hough, James. The History of Christianity in India. 4 vols. London: R. B. Selay and W. Burnside, 1839.

Howard, George Broadly. The Christians of St. Thomas and Their Liturgies. London: John Henry James Parker, 1864 .

Hyatt, Harry Middleton. The Church of Abyssinia. London: Luzac \& Co., 1928.

Isaac, Ezekiel Malekar. "The Jewish Community in India and Their Personal Law." Religion and Society 38 (1991): $48-63$.

Israel, J. Benjamin. The Bene Israel of India. Bombay: Orient Longman, 1984.

"John." Seventh-day Adventist Bible Commentary. Rev. ed. Edited by F. D. Nichol. Washington, D.C.: Review and Herald, 1980. 5:891-1073.

John, M. O. The St. Thomas Christians in India. Ernakulum, Kerala: Korah Varghese, 1987.

Joseph, M. O. Kerala Kristhi Yanikal [History of Christians in Kerala]. Cochin, Kerala: LFI, 1972.

Kanookadan. "The Development of the Syriac Lectionary system." The Harp 10 (1997): 11-51.

Keay, F. E. A History of the Syrian Church in India. Madras: ISPCK, 1938. 
Kessler, K. "Nestorians." The New Schaff-Herzog Encyclopedia of Religious Knowledge. 1910 ed. 8:120123.

Klijn, A. F. The Acts of Thomas. Leiden: Brill, 1962.

Koonammakal, Thomakathanar. "Semitic Dimension of Christian Tradition." The Harp 10 (1997): 71-75.

Koshy, K. E. History of St. Thomas. Thiruvalla, Kerala: MGM, 1954.

Kraft, Charles H. "What Kind of Encounter Do We Need in Our Christian Witness?" Evangelical Missions Quarterly (July 1991): 258-265.

Krishnankutty, Thiruvattar. Yesu Kristhu Sampoorna Viplavakari [Jesus Christ the Complete Revolutionist] . Eraviperoor, Kerala: Noble, 1988.

Latourette, Kenneth Scott. A History of the Expansion of Christianity. Vol. 1, The First Five Centuries. Grand Rapids: Zondervan, 1974.

Layton, Bentley. The Gnostic Scriptures. New York: Doubleday, 1995.

Lobley, J. A. The Church and Churches in South India. London: Deighton, Bell and Co., 1870.

Logan, William. Malabar. 2 vols. New Delhi: Asian Educational Service, 1989.

Lukose, K. K. Christians in Malabar. Nagarcoil, Tamil Nadu: London Missionary Press, 1943.

Malankara Catholic Directory. Trivandrum, Kerala: St. Mary's Offset, 1999.

Malayala Manorama Year Book. Kottayam, Kerala: Manorama, 1999 .

Mar Thoma Sabha Diary. Thiruvalla, Kerala: Mar Thoma Syrian Church, 1995.

Mathew, P. V. Acta Indica. Cochin, Kerala: Ladies Service Centre, 1986. 
Mathew, P. M. Kananya Sabha Charithram [History of the Kananaya Church]. Chingavanam, Kerala: Kananya, 1996.

Maxson, D. E. "Seventh-day Baptists." Religious Encyclopedia. 1891. 2165-2167.

Mayers, H. H. The Inquisitive Christians. Morisset, N.S.W.: New Millennium, 1992.

McGavran, Donald A. Understanding the Church in India. Bombay: Gospel Literature Service, 1979.

Menacherry, George. The St. Thomas Christian Encyclopedia of India. 2 vols. Trichur, Kerala: St. Thomas Christian Encyclopedia of India, 1982.

Menon, Sreedharan A. Survey of Kerala History. Madras: S. Viswanathan, 1994.

Menon, K. P. History of Kerala. 3 vols. New Delhi: Asian Educational Service, 1984.

Mingana, A. "The Early Spread of Christianity in India." The Bulletin of the John Rylands Library 10 (July 1926): 1-85.

Moffett, Samuel H. A History of Christianity in Asia. Vol. 1, Beginning to 1500. Maryknoll, N.Y.: Orbis, 1998.

Mohan, G. U. D. Interview by author. Pallippad Panchayet, Kerala, June 23, 2000.

Moraes, George Mark. A History of Christianity in India. 5 vols. Bombay: Manaktala, 1964.

Mundadan, A. M. History of Christianity in India. 2 vols. Bangalore: Theological Publications in India, 1984.

- St. Thomas Christians, 1498-1552. Bangalore: Charmaram College, 1967.

- Sixteenth Century Traditions of St. Thomas Christians. Bangalore: Dharmaram College, 1970.

Neill, Stephen. A History of Christianity in India. 2 vols. London: Cambridge University Press, 1985.

Nicolo, Conti. Quoted in Mayer, H. H. The Inquisitive Christians. Morisset N.S.W.: New Millenium, 1992. 
Nixon, R. E. "Thomas." The Illustrated Bible Dictionary. 1980 ed., Wheaton, Ill.: Tyndale, 1980. 3:558-559.

Orthodox Syrian Church Diary. Kottayam, Kerala: MGOCSM, 1997.

Paul, D. Babu. The syrian Orthodox Church of St. Thomas. Trivandrum, Kerala: T. P. Mathew, Samudaya Secretary, 1995.

Vedha Ratna Karam [Bible Dictionary]. Trivandrum, Kerala: State Institute of Language, 1997.

Pelog, Vander. The Christians of St. Thomas in South India and Their Manuscripts. Bangalore: Dharmaram, 1983.

Philip, A. T. The Mar Thoma Church and Kerala Society. Trivandrum, Kerala: Juhanan Mar Thoma Study Centre, 1991.

Philip, E. M. The Indian Church of St. Thomas the Apostle. Kottayam, Kerala: Bharat, 1907.

Pillai, K. K. South Indian History. Trichur, Kerala: Current Books, 1960.

Podipara, Placid J. The Malabar Christians. Alleppey, Kerala: Prakasam, 1972.

- The Thomas Christians. Bombay: St. Pauls, 1970.

Ponraj, S. D. Pioneers of the Gospel Mission. Madhupur, Bihar: Education Books, 1993.

Priolkar, A. K. The Goa Inguisition. Bombay: University Press, 1961.

Purchas, Samuel. His Pilgrims. 8 vols. New York: AMS Press, 1965.

Pylee, L. M. St. Thomas Christians and the Archdiocese of Verapoly. Ernakulam, Kerala: St. Joseph Industrial School, 1977.

Rae, George Milne. The Syrian Church in India. London: William Blackwood and Sons, 1892.

Read, William R. New Patterns of Church Growth in Brazil. Grand Rapids: Eerdmans, 1965. 
Richards, W. J. The Indian Church of St. Thomas. London: Bemrose \& Sons, 1908.

Robb, John D. Eocus! The Power of People Group Thinking. Lalgarh, Bihar: MARC, 1994.

Roberts, Alexander, and James Donaldson, eds. Ante-Nicene Fathers. 10 vols. Grand Rapids: Eerdmans, 1957.

Sakthidharan, Suchitra, President of Panchayat. Interview by author. Pallippad, April 13, 2000.

Sam, D. History of the Catholic Church in India. 2 vols. Bombay: B. X. Furtado \& Sons, 1910.

Sardar, Ashok. "Sunday Not Holy Day." The Chilliwack Progress, July $30,1986,1-2$.

Sathya Pradeepa Ganagal [Truth in Song]. $5^{\text {th }}$ ed. Thiruvananthapuram, Kerala: South Kerala Section of SDA, n.d.

Schaff, Philip. History of the Christian Church. Vol. 1. Ante-Nicene Christianity. Edinburgh: T. and T. Clark, 1893.

, ed. The Nicene and Post Nicene Eathers.

2d series. Grand Rapids: Eerdmans, 1961.

Schaffman, Lawrence H. "Essenes." The Encyclopedia of Religion. 1987 ed. 5:163-166.

Shams, J. D. Where Did Jesus Die? 9th ed. Tiford, Surrey, UK: Islam International, 1992.

Soggard, Viggo. Media in Church and Mission. Pasadena: William Carey, 1993.

Steffen, Tom A. Passing the Baton: Church Planting That Empowers. La Habra, Calif.: Center for Organizational and Ministry Development, 1993.

Stewart, J. Nestorian Missionary Enterprise. Trichur, Kerala: Mar Narsai, 1961.

Strand, Kenneth A., ed. The Sabbath in Scripture and History. Washington, D.C.: Review and Herald, 1982. 
Stuart, Benedict Dom. The Development of Christian Worship. London: Longman Green, 1953.

Thomas, A. K. The Christians of Kerala. Kottayam, Kerala: DC Offset, 1993.

Thomas, Matthew. Indian Church of St. Thomas. New Delhi: ISPCK, 1967.

Thomas, M. K. Kananayakaram Puthiya Niyamaum [Canaanites and New Testament]. Trivandrum, Kerala: Arimathia, n.d.

Thomas, P. Churches in India. New Delhi: Publications Division, Ministry of Information and Broadcasting, Government of India, 1990.

"The Canaanites of Kerala, Ancient Outpost of Judeo-Christianity," 1980. Unpublished Manuscript, Public Library, Thiruvananthapuram, Kerala.

Timberg, Thomas A. Jews in India. Sabidabad, Uttar Pradesh: Vikas, 1986.

Tisserant, C. E. Eastern Christianity in India. London: Longmans Green, 1957.

Vadakkekara, Benedict. Origin of India's St. Thomas Christians. Delhi: Media House, 1995.

Vasantharaj, Albert. Orissa Church and People Groups. Madras: Church Group Association, 1992.

Walker, williston. A History of the Christian Church. 2 vols. New York: Charles Scribners \& Sons, 1959.

Warren, Rick. The Purpose Driven Church. Grand Rapids: Zondervan, 1995.

Way, Ritchie, "Home Group Ministry Helps Your Church Grow." Ministry, February 1992, 10.

Weizman, Ezer. "The Jewish President's Visit." Malayala Manorama Daily Newspaper, January 3, 1997, 4.

White, Ellen G. Child Guidance. Washington, D.C.: Review and Herald, 1982 .

- Christian Service. Washington, D.C.: General Conference of Seventh-day Adventists, 1947. 
Desire of Ages. Mountain View, Calif.: Pacific Press, 1940. Herald, 1974 .

- Evangelism. Washington, D.C.: Review and - Testimonies to the Church. 9 vols. Mountain View, Calif.: Pacific Press, 1948.

Wilkinson, B. G. Truth Triumphant. Mountain View, Calif.: Pacific Press, 1944.

Woolsey, Raymond H. Evangelism Handbook. Washington, D.C.: Review and Herald, 1972.

Zacharia, Scaria. The Acts and Decrees of the Synod of Diamper, 1599. Edamattam, Kerala: Indian Institute of Christian Studies, 1994. 
VITA

\section{Personal Backoround}

Name

Date of Birth

Place of Birth

Married

Wife's Name

Children

\section{Academic Experience}

1967

1976

1985

1990

\section{Working Experience}

1992-

1976-1991
K. Yohannan

April 5, 1951

Chengannur, Kerala

January 8, 1980

Thankamma K. Yohannan

Tinu K. Tharakan

Tiju K. Tharakan

SSLC, St. John's High School,

Mattom Mavelikara, Kerala, India

Two-year Bible Instructor, Spicer

Memorial College, Pune, India

Bachelor of Liberal Arts, Spicer

Memorial College, Pune, India

Master of Arts, Andrews University, Spicer Memorial College Examination Center, Pune, India

Ministerial Secretary, South Kerala Section of SDA, Thiruvananthapuram, Kerala

Church Pastor, Kallara, Thalikuzhy, Bharathanoor, Thiruvalla, Nedungadappally, Punnavely, in

South Kerala Section of SDA 